\title{
Interpreting International Law in Context - Domestic Specificities
}

\begin{abstract}
What I am convinced of is the need to start with some particularization. I don't find myself at all convinced when people start out claiming they can tell us about judging without some grounding in a specific imagined situation. ${ }^{275}$
\end{abstract}

[T] he interpretation of international law is culturally sensitive and needs to be analysed in light of the legal, political and social contexts of the different domestic legal orders. ${ }^{276}$

In this chapter, I highlight several characteristics of the Swiss legal order that deserve emphasis for the purposes of this study. ${ }^{277}$ These characteristics fall into three categories. A first cluster of features pertains to the relationship between the Swiss State and international law (2). It encompasses the characteristics, principles, and goals of Swiss foreign relations law and policy (2.1), and the way the Swiss legal order regulates its relationship with international law (2.2). I then highlight a series of principles of political organization that govern the Swiss State (3): federalism (3.1), linguistic diversity (3.2), the rule of law (3.3), semi-direct democracy (3.4), and legislative supremacy (3.5). Third, I focus on the structure, organization, and functioning of the Swiss judiciary (4), before concluding (5).

As stated at the outset (supra, Chapter 1, section 3), I do not look at the interpretation of international law by domestic courts in abstracto. I focus on

275 Kennedy, 'Freedom and Constraint in Adjudication: A Critical Phenomenology' (n 75) 45.

276 Aust and Nolte (n 47) v.

277 Many characteristics mentioned in this chapter have originally been identified in Besson and Ammann (n 6o). 
a given institutional and domestic legal context, ${ }^{278}$ and on how courts have decided specific cases. Refraining from focusing on a specific domestic judiciary and on individual cases would lead to an analysis that lacks substance. It would also make it difficult to provide a thorough, reasonably comprehensive, and nuanced account of the challenges and constraints domestic courts face. International law is designed to be implemented in domestic legal orders, which differ in terms of their legal, institutional, and political structures. It would be artificial to sever the domestic case law from the context in which it is nested. Jurisdiction-specific approaches to international law in domestic courts have been widely adopted by international legal scholars, ${ }^{279}$ and the blending of such approaches with the methods of comparative law has even given birth to a field of its own: 'comparative international law'.280

Highlighting the specificities of the Swiss legal order that are significant for an analysis of the Swiss judicial practice of international law has several aims. First, as Duncan Kennedy puts it, these idiosyncrasies are part of the legal 'material' with which Swiss courts have to 'work' when applying international law domestically. ${ }^{281}$ Disentangling this domestic 'thicket'282 makes it possible to identify some of the legal (and other) reasons for which Swiss courts interpret international law in a given way. ${ }^{283}$ Second, domestic law must be factored into any normative appraisal of domestic judicial practices. Third, the present list is also a preliminary step to mapping the Swiss judicial practice of international law through empirical work. ${ }^{284}$ Fourth, and importantly, this chapter sets the

278 Etymologically, 'context' points to what is weaved together (from con-, with, and -texere, to weave). A contextual approach aims at disentangling a set of circumstances that are knit together and form the background of an issue or activity.

279 Sloss (n 120); Aust and Nolte (n 47); August Reinisch, International Organizations Before National Courts (Cambridge University Press 2000).

280 Roberts and others (n 8). See also Mathias Forteau, 'Comparative International Law Within, Not Against International Law: Lessons From the International Law Commission' (2015) 109 American Journal of International Law 498. While I do not engage in a comprehensive comparative legal analysis, I will refer to the practices of courts in other States to put the Swiss case law into perspective (see Chapters 7 and 8, infra).

281 Kennedy, 'Freedom and Constraint in Adjudication: A Critical Phenomenology' (n 75).

282 Carter and Weiner (n 89) 15 o.

283 On the importance of this question, see Manuel J Ventura, 'Book Review: Sharon Weill, The Role of National Courts in Applying International Humanitarian Law' (2016) 14 Journal of International Criminal Justice 744. On the us historical context, for example, see Bradley and Goldsmith (n 171) ch 1; David L Sloss, Michael D Ramsey, and William S Dodge (eds), International Law in the U.S. Supreme Court: Continuity and Change (Cambridge University Press 2011).

284 Ammann, 'International Law in Domestic Courts Through an Empirical Lens: The Swiss Federal Tribunal's Practice of International Law in Figures' ( $n_{5}$ ). 
stage for the argument that guides this entire study. As will become apparent, several features of the Swiss legal order explain why the Swiss judicial practice of international law has been predominantly outcome-oriented, anti-theoretical, and deferential towards other branches of government. Yet if Swiss courts are to interpret international law - as opposed to doing something else that does not qualify as such - they must strive to bring their practice into conformity with the interpretative methods of international law, and they must offer predictable, clear, and consistent reasoning in support of their conclusions.

Several caveats apply to this chapter. First, I predominantly flesh out the legal characteristics of the Swiss legal order. Of course, myriad extra-legal peculiarities (be they sociological, ${ }^{285}$ psychological, ${ }^{286}$ or anthropological, ${ }^{287}$ to name but a few examples) explain the domestic judicial practice of international law from an 'external'288 vantage point and deserve attention. For reasons of scope and expertise, I take these other approaches into account only at the margins. However, the line between 'legal' and 'extra-legal' features is not a sharp one, as providing insights into Swiss judges' 'internal point of

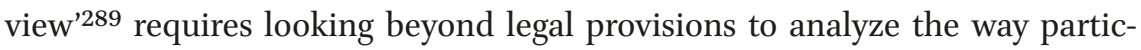
ipants in legal practices think, talk, and argue about the law. Hence, I also include aspects that are not strictly 'legal' (in the sense of being provided for under Swiss law) but that shed light on the Swiss case law.

Second, while I believe to have included what are, for the purpose of this study, noteworthy features of the Swiss legal order, I have certainly not exhausted all the legal characteristics that define the Swiss judicial practice of international law and distinguish it from that of other domestic courts. Additional features include procedural law, for instance, or areas of domestic law that have no obvious connection to international law, but are relevant to a given case.

Third, the facets I highlight should not be considered in isolation. Quite to the contrary, they are likely to influence each other.

\footnotetext{
285 Simone Rau and Barnaby Skinner, 'Das sind die härtesten Asylrichter der Schweiz' (Tagesanzeiger, 2016)<blog.tagesanzeiger.ch/datenblog/index.php/12556/je-nach-richterdreimal-hoehere-erfolgschancen>.

286 Hänni ( $\mathrm{n} 75)$.

287 Sally Engle Merry, 'Transnational Human Rights and Local Activism: Mapping the Middle’ (2006) 108 American Anthropologist 38.

288 On external approaches in legal scholarship, see McCrudden (n 7). On the relationship between these approaches and international law, see Besson, 'International Legal Theory qua Practice of International Law' (n 204).

289 Hart (n 78) $82 \mathrm{ff}$.
} 
Lastly, the significance of the domestic legal context does not mean that domestic courts are not, or must not, be guided by international law, which is the main focus of this study. From the perspective of international law, domestic law cannot in principle justify a State's violation of its international obligations. ${ }^{290}$ The international legal framework that governs domestic courts' interpretation of international law is analyzed in more detail in Chapters 4 and 6 (infra).

A first cluster of legal specificities that deserves emphasis concerns the relationship between the Swiss State and international law. The goals, principles, and characteristics of Swiss foreign relations law (2.1), and the status, rank, and direct effect of international law in the Swiss legal order (2.2) all constrain Swiss courts' adjudication of international legal issues.

\subsection{Swiss Foreign Relations Law}

Foreign relations law is the body of legal acts that defines the relationship of a State (or of another subject of international law) with other international legal subjects, as well as the rights, duties, and powers of international legal subjects in this context. It must be distinguished from the State's foreign policy, which is primarily driven by strategic, as opposed to legal, considerations (though legal aspects will often be of great importance). In practice, foreign relations law and foreign policy are intermingled: policy goals are achieved through law, which constrains and enables policy, and which defines its general orientation.

What is the relevance of foreign relations law for domestic courts' interpretation of international law? A State's foreign relations law determines the type of international legal issues that can be brought before its courts, and it constrains the way in which courts can resolve such issues. It can also make this State 'specially affected' ${ }^{291}$ by specific international legal acts ${ }^{292}$ (besides other

290 Art. 27 VCLT.

291 ICJ, case concerning the North Sea Continental Shelf (Germany v. Denmark; Germany v. Netherlands), merits, judgment, ICJ Reports 1969, 20 February 1969, 3, at 42 f, para $73 \mathrm{f}$. See also ICJ, case concerning the Legality of the Threat or Use of Nuclear Weapons, advisory opinion, ICJ Reports 1996, 8 July 1996, 226, at 253 f, para 65.

292 Eg States that have concluded specific treaties, are nuclear powers, or are engaged in an international armed conflict. 
factors, eg geography). ${ }^{293}$ While some reject the concept of 'specially affected States' due to sovereign equality and States' interconnectedness, ${ }^{294}$ others contend that if a State is particularly exposed to specific international legal issues, particular weight should be conferred to its practice and opinio juris for the purposes of ascertaining CIL. ${ }^{295}$ In any case, whenever a State is one of the few (or even the only one) to have faced a given international legal issue, its practice will likely be taken into account by other States to determine what international law requires. ${ }^{296}$

In this subsection, I first highlight the general characteristics of Swiss foreign relations law (2.1.1), before focusing on the domestic separation of powers in foreign relations (2.1.2).

\subsubsection{Swiss Foreign Relations Law in General}

The Swiss Constitution states that in its foreign relations, the federal State 'shall ensure that the independence of Switzerland and its welfare is safeguarded' and 'assist in the alleviation of need and poverty in the world and promote respect for human rights and democracy, the peaceful coexistence of

293 For an example: Bernard H Oxman, 'Some Observations on the Draft Conclusions on Identification of Customary Law Provisionally Adopted by the ILC's Drafting Committee at the Sixty-Sixth Session' (2014) AJIL Unbound <www.asil.org/blogs/someobservations-draft-conclusions-identification-customary-law-provisionally-adoptedilc\%25E2\%2580\%2599s>.

294 Dissenting opinion of Judge Shahabuddeen in ICJ, case concerning the Legality of the Threat or Use of Nuclear Weapons, advisory opinion, ICJ Reports 1996, 8 July 1996, 375, at 414; dissenting opinion of Judge Weeramantry in ibid 429, at 536 . The concept was initially included, but later removed from the ILC's draft conclusions on CIL. Compare the following reports: ILC, 'Third Report on Identification of Customary International Law by Michael Wood, Special Rapporteur' (2015) Un Doc A/CN.4/682; ILC, 'Fourth Report on Identification of Customary International Law by Michael Wood, Special Rapporteur' (2016) Un Doc A/CN.4/695. See also Un General Assembly, Report of the ILC, 67th session (4 May-5 June and 6 July - 7 August 2015), UN Doc A/70/10, 44, para 82.

295 ICJ, case concerning the Legality of the Threat or Use of Nuclear Weapons, advisory opinion, ICJ Reports 1996, 8 July 1996, 226, at 253 f, para 65. Some States emphasized the practice and opinio juris of 'those [States] who possess [nuclear] weapons' to suggest the existence of CIL prohibiting the threat or use of nuclear weapons. See also ILC, 'Fifth Report on Identification of Customary International Law by Michael Wood, Special Rapporteur' (2018) UN Doc A/CN.4/717 $29 \mathrm{ff}$ para $64 \mathrm{ff}$.

296 One example is the Pinochet litigation in the House of Lords. See ILC, 'Fragmentation of International Law: Difficulties Arising From the Diversification and Fragmentation of International Law' (2006) Un Doc A/CN.4/L.682 para 187 at 371. For a critique, see Ingrid Wuerth, 'Pinochet's Legacy Reassessed' (2012) 106 American Journal of International Law 731 . 
peoples as well as the conservation of natural resources'. ${ }^{297}$ Another provision that indicates the orientation of Swiss foreign relations is the Confederation's commitment 'to a just and peaceful international order'. ${ }^{298}$ While case law on these constitutional goals and principles is non-existent, concretizations can be found in legislation, ${ }^{299}$ as well as in a number of governmental documents. ${ }^{300}$ The Foreign Policy Strategy Report for 2016-19, for instance, enumerates the foundational principles of Swiss foreign relations: the rule of law, neutrality, universality, dialogue, solidarity, responsibility, efficiency, and coherence. $^{301}$

The commitment of the Swiss State to the rule of law in both interstate and intrastate matters figures among the basic principles of Swiss foreign relations, ${ }^{302}$ and it is included (either explicitly or through related terms, such as 'legal certainty') under three of the four strategic priorities mentioned in the Swiss Foreign Policy Strategy Report. ${ }^{303}$ The rule of law also appears in numerous passages of the Federal Council's Foreign Policy Report. ${ }^{304}$ The federal government has linked Switzerland's attachment to the rule of law to its acceptance of the ICJ's compulsory jurisdiction under art. 36(2) ICJ Statute, ${ }^{305}$

297 Art. 54(2) Cst.

298 Art. 2(4) Cst.

299 See especially the FA-CPP.

300 Such documents include the Foreign Strategy Report, which the FDFA submits to the Federal Council at the beginning of a legislative term (FDFA, Swiss Foreign Policy Strategy 2016-19: Federal Council Report on the Priorities for the 2016-19 Legislative Period, $<$ www.dfae.admin.ch/content/dam/eda/en/documents/publications/Schweizerische Aussenpolitik/Aussenpolitische-Strategie-160301_EN.pdf>), and the annual Federal Council's Foreign Policy Report (Federal Council, Foreign Policy Report 2018, F G 2019 $15^{\circ}$, < www.admin.ch/opc/de/federal-gazette/2019/1505.pdf>). The FDFA intermittently publishes reports on specific foreign policy issues, such as neutrality, international cooperation, and counter-terrorism, and several periodicals.

301 FDFA, Swiss Foreign Policy Strategy 2016-1 9 (n 300) 11 ff.

302 Ibid 5 .

303 Ie, 'relations with the European Union and the EU and EFTA member states', 'relations with global partners', 'peace and security', and 'sustainable development and prosperity', ibid $14 \mathrm{ff}$.

304 Federal Council, Foreign Policy Report 2018 (n 300); for an earlier example, see Federal Council, Foreign Policy Report 2015, FG 2016 503, <www.admin.ch/opc/fr/federalgazette/2016/503.pdf>, 537 f; $549 \mathrm{ff} ; 610 \mathrm{ff}$.

305 FDFA, Handbook on Accepting the Jurisdiction of the International Court of Justice: Model Clauses and Templates, 2014, <www.eda.admin.ch/content/dam/eda/en/documents/ publications/Voelkerrecht/handbook-jurisdiction-international-court_en>. See also $<$ www.icj-cij.org/jurisdiction/?p1=5\&p2=1\&p3=3\&code $=\mathrm{CH}>$. 
to its cooperation with the ad hoc international criminal tribunals, ${ }^{306}$ and to its ratification of the ICC Statute. ${ }^{307}$ It has also mentioned it in connection with the ECHR, ratified by Switzerland in 1974, ${ }^{308}$ and with the ICCPR and ICESCR, which Switzerland ratified in 1992. ${ }^{309}$ This commitment to the rule of law also manifests itself via the Swiss government's efforts to push reforms of the UN Security Council ${ }^{310}$ and the UN treaty bodies. ${ }^{311}$

Another salient feature of Swiss foreign affairs is Switzerland's neutrality. ${ }^{312}$ It explains why Switzerland has been reluctant (or has refused) to join IOs such as the UN (Switzerland became a member in 2002), ${ }^{313}$ NATO (Switzerland is not a party to the 1949 North Atlantic Treaty), the EU (Switzerland is not an EU member State), and the EEA (Swiss voters rejected a proposed adhesion in 1992). The law of neutrality being relevant for the Swiss legal order, Switzerland is a 'specially affected State' in this regard.

306 Federal Council, Botschaft betreffend den Bundesbeschluss über die Zusammenarbeit mit den Internationalen Gerichten zur Verfolgung von schwerwiegenden Verletzungen des humanitären Völkerrechts, 18 October 1995, FG 1995 IV 1101, for instance at 1105.

307 Federal Council, Botschaft über das Römer Statut des Internationalen Strafgerichtshofs, das Bundesgesetz über die Zusammenarbeit mit dem Internationalen Strafgerichtshof und eine Revision des Strafrechts, 15 November 2000, FG 2001 391, for instance at 406, 431, and 483 .

308 Federal Council, 4o Jahre EMRK-Beitritt der Schweiz: Erfahrungen und Perspektiven, Bericht des Bundesrates in Erfüllung des Postulats Stöckli 13.4187 vom 12. Dezember 2013, 14 November 2014, FG 2015 357, at 359, 407 f, 410. The ECHR was ratified after the removal of two constitutional obstacles. First, women's suffrage was introduced in 1971. Then, in 1973, the so-called 'confessional articles' of the Swiss Constitution (which discriminated against the Jesuits, and prohibited both the creation of new monasteries or religious orders and the restoration of abolished ones) were abrogated.

309 Federal Council, Botschaft betreffend den Beitritt der Schweiz zu den beiden internationalen Menschenrechtspakten von 1966 und zu einer Änderung des Bundesrechtspflegegesetzes vom 3o. Januar 1991, 2 April 1991, FG 1991 I 1189, at 1196.

$310<$ www.eda.admin.ch/missions/mission-new-york/en/home/working-methods-of-thesecurity-council.html $>$.

$311<$ www.un.org/ruleoflaw/blog/portfolio-items/switzerland-strengthening-andenhancing-the-effective-functioning-of-the-human-rights-treaty-body-system>.

312 For an analysis of Switzerland's history of neutrality from the perspective of international law, see Detlev F Vagts, 'Editorial Comment: Switzerland, International Law and World War II' (1997) 91 American Journal of Jurisprudence 466.

313 In 1947, Manley O Hudson wrote: 'As [Switzerland] had stayed out of all but humanitarian action through two World Wars, she was not to be regarded in 1945 as a "peace-loving" state. Of course the scenes on the stage of 1945 have now shifted to some extent, and possibly Switzerland could today qualify for United Nations membership. She has made no application for such membership, however, and her centuries-old tradition of neutrality may keep her from shouldering the obligations of the Charter for many years to come'. See Hudson (n 1) 867 . 
Its neutrality notwithstanding, and in line with its commitment to the rule of law in international relations, Switzerland has entered into a number of international legal relationships with States and other subjects of international law. It has concluded two sets of bilateral agreements with the $\mathrm{EU}$, and it has ratified a wide range of other bilateral and multilateral treaties. ${ }^{314}$ Switzerland is a member of an array of international and regional organizations, including the UN, the WTO, the Council of Europe, the EFTA, the OSCE, and the OECD, and it cooperates with NATO through the 'Partnership for Peace' program.

Partly owing to its neutrality, Switzerland is the host State of an important number of IOs and UN agencies. The headquarters of these organizations are mostly in Geneva. The city harbors one of the four main offices of the UN, the ICRC, the ILO, the WHO, the WIPO, the ISO, and many other organizations. ${ }^{315}$ Other Ios are based in Basel (where the BIS has its seat) or Bern (where the Universal Postal Union and the Intergovernmental Organization for International Carriage by Rail are located). The presence of these organizations on Swiss territory is governed by domestic legal provisions ${ }^{316}$ and international treaties ${ }^{317}$ which clarify these organizations' rights and duties, including the privileges and immunities granted by the host State. The international law on privileges and immunities of States, IOs, and their agents is hence relevant to the Swiss judicial practice of international law and makes Switzerland a 'specially affected State' in this respect. ${ }^{318}$ It is worth noting that due to the presence of these organizations, Switzerland is the depositary of many treaties (eg the Geneva Conventions). ${ }^{319}$

314 For an overview: <www.admin.ch/opc/de/classified-compilation/international.html $>$.

$315<$ www.eda.admin.ch/eda/en/fdfa/foreign-policy/international-organizations/ international-organizations-switzerland.html >.

316 See especially the Federal Act on the Privileges, Immunities and Facilities, and the Financial Subsidies Granted by Switzerland as a Host State of 22 June 2007 (SR 192.12).

317 As of June 2019, Switzerland had entered into headquarters agreements with 27 IOs: see <www.eda.admin.ch/eda/en/home/foreign-policy/international-organizations/ international-organizations-switzerland.html>.

318 On the Swiss practice in this area, see Neumann and Peters (n 12).

319 As of June 2019, Switzerland was the depositary of 79 treaties. See < www.dfae.admin.ch/ eda/en/home/aussenpolitik/voelkerrecht/internationale_vertraege/depositar.html>. On the functions of depositaries, see Claude Schenker, 'Dépositaire: une impartialité sous surveillance. L'exemple de la Suisse' (2018) 28 Swiss Review of International and European Law 25. 


\subsubsection{Domestic Separation of Powers in Foreign Relations}

The domestic separation of powers defines the respective competences of the three branches of government in foreign relations. ${ }^{320}$ It constrains domestic courts' interpretation of international law by specifying the instances in which courts are legally required to defer to the other branches.

Regarding the horizontal (inter-branch) separation of powers, the Swiss Constitution provides that foreign relations are the primary responsibility of the federal government (the Federal Council). ${ }^{321}$ The government has the power to sign and ratify treaties, ${ }^{322}$ which in principle require the subsequent approval of the federal parliament (the Federal Assembly). ${ }^{323}$ In practice, and like in many States, ${ }^{324}$ the Federal Council often ratifies treaties based on its independent powers to do so. ${ }^{325}$ As far as the judiciary is concerned, the Swiss Federal Tribunal has the duty to apply international law, ${ }^{326}$ although some foreign relations issues fall outside of its jurisdiction (infra, 4.2.1). The Federal Assembly 'participate[s] in shaping foreign policy and supervise[s] the maintenance of foreign relations'. ${ }^{327}$ The parliamentary powers in foreign relations should not be underestimated. The Federal Assembly comprises two Foreign Policy Committees (one for each house). The Committees examine specific issues referred to them, and they formulate proposals in their area of responsibility. ${ }^{328}$ The Federal Council regularly informs and consults them. ${ }^{329}$ By launching initiatives and parliamentary interventions, the Committees can raise issues related to foreign relations. ${ }^{330}$

It is worth mentioning that in the past, the Swiss constitutional order provided for a 'co-mingling of the powers of government', ${ }^{331}$ as the federal

320 For an analysis of international law in domestic courts from the perspective of the constitutional separation of powers: David Haljan, Separating Powers: International Law Before National Courts (TMC Asser Press 2013).

321 Art. 184(1) Cst.

322 Art. 184(2) Cst.

323 Art. 166(2) Cst.

324 One example is the high practical relevance of sole executive agreements in us foreign relations.

325 Art. 7a of the Federal Government and Administration Organization Act of 21 March 1997 (SR 172.010).

326 Art. 190 Cst.

327 Art. 166(1) Cst.

328 Art. 44 FA-FA.

329 Art. 152 FA-FA.

330 Art. 45(1)(a) FA-FA.

331 Ruth D Masters, International Law in National Courts: A Study of the Enforcement of International Law in German, Swiss, French and Belgian Courts (Columbia University Press 1932) 9o. 
parliament and the federal executive both exercised 'executive, legislative, and judicial functions. ${ }^{332}$ This 'co-mingling' was starkly attenuated by subsequent constitutional amendments.

The Constitution further clarifies the vertical separation of powers between the Confederation and the cantons in international relations (see also infra, 3.1). While foreign affairs are a federal matter, ${ }^{333}$ the cantons must be consulted by the federal government whenever their interests are affected by a decision, ${ }^{334}$ and these interests must be respected by foreign policy. ${ }^{335}$ The cantons also have limited treaty-making powers. ${ }^{336}$

\subsection{International Law in the Swiss Legal Order}

Another feature that constrains Swiss courts' interpretative activity concerns the way the Swiss legal order regulates its relationship to international law, ie, the status (2.2.1), rank (2.2.2), and direct effect (2.2.3) of international law. ${ }^{337}$ Given the scarce guidance provided by the Swiss Constitution on these issues, emphasis is placed on the practice of the Swiss authorities. The Swiss Federal Tribunal in particular has clarified several aspects of this relationship.

\subsubsection{Status}

The domesic status of international law pertains to the conditions under which international law becomes an integral part of domestic law. In this regard, States oscillate between two poles: monism and dualism. Monism does not require that international law be transposed into domestic law to be valid in the domestic legal order. By contrast, dualism demands such a transposition. It is based on a conception of domestic and international law as two separate, 'self-contained'338 sets of norms that 'never overlap.' ${ }^{339}$

\footnotetext{
332 See ibid 91.

333 Art. 54(1) Cst.

334 Art. 55(1) Cst; Federal Act on the Participation of the Cantons in the Foreign Policy of the Confederation of 22 December 1999 (SR 138.1).

335 Art. 54(3) Cst.

336 Art. 56(1) Cst.

337 See already Besson and Ammann (n 6o). See also (with references): Besson, Droit international public: Abrégé de cours et résumés de jurisprudence (n 89) $303 \mathrm{ff}$.

338 Giorgio Gaja, 'Dualism: A Review' in Janne E Nijman and André Nollkaemper (eds), New Perspectives on the Divide Between National and International Law (Oxford University Press 2007) 52.

339 In the original: 'deux cercles qui sont en contact intime, mais qui ne se superposent jamais'; Heinrich Triepel, 'Les rapports entre le droit interne et le droit international' (1923) 1 Recueil des cours de l'Académie de droit international 83.
} 
Overall, Swiss law and practice endorse monism: the Constitution does not require that treaties be transposed to be part of the domestic legal order, ${ }^{340}$ all levels of government must respect international law, ${ }^{341}$ courts must apply international law, ${ }^{342}$ and constitutional amendments cannot disregard so-called mandatory provisions of international law. ${ }^{343}$ The Swiss Federal Tribunal has mentioned the monism of the Swiss legal order early on, ${ }^{344}$ and it endorses it with regard to all sources of international law..$^{345}$ On the other hand, some of the Court's early rulings were clearly dualist, ${ }^{346}$ and past scholarly writings have stated that 'Swiss jurists adhere to the dualistic theory'. ${ }^{347}$ While several proposals to switch to dualism have been made at the federal legislative level, ${ }^{348}$ they have never garnered enough parliamentary support. They have also been consistently rejected by the Federal Council. ${ }^{349}$

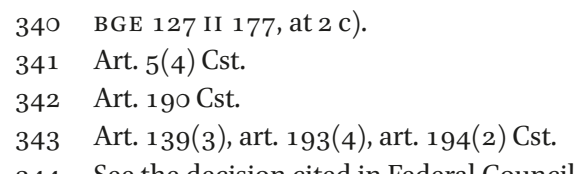

344 See the decision cited in Federal Council, Botschaft an die Bundesversammlung betreffend die Mitwirkung der Schweiz bei Ausführung der Generalakte der Konferenz von Algesiras vom 7. April 1906, FG 1907 II 112, 15 March 1907, at 119; the case is mentioned by Masters (n 331) 96. See also ibid 98. For later decisions, see eg BGE 132 III 122, at 3.1.1 (explicit reference to monism with primacy of international law); BGer, judgment 9C_873/2012 of 25 February 2013, at 4.2 (explicit reference to monism); BGE 130 I 312, at 4.1 (explicit reference to monism with primacy of international law); BGE 122 II 234, at 4 a), and BGE 94 I 669, at 2 (implicit references to monism).

345 BGer, judgments 2A.783/2006, 2A.784/2006, and 2A.785/2006 of 23 January 2008, at 7.1; BGE 133 II 450, at 6.1; BGE 44 I 49, at 4. See further: BGer, judgment 2C_95o/ 2012 of 8 August 2O13, at 2.2 (treaties); BGE $115 \mathrm{Ib} 496$, at 5 b) (CIL); BGer, judgment 1A.63/2002 of 9 April 2002, at 2.1 (general principles of international law). See for instance Astrid Epiney, 'Das Verhältnis von Völkerrecht und Landesrecht aus der Sicht des Bundesgerichts: Anmerkung zum BGE 2C_828/2011 vom 12. Oktober 2012' Jusletter of 18 March 2013 .

346 BGE 49 I 188, at 3, cited in Masters (n 331) 97.

347 See ibid 98.

348 Lukas Reimann, Motion 14.3221 and Motion 16.3239, Dualismus statt Monismus, 27 May 2014 and 3 May 2016; Swiss People's Party, Postulat o9.3676, Völkerrecht und Landesrecht: Systemwechsel vom Monismus zum Dualismus, 11 June 20o9; Christoph Mörgeli, Interpellation 04.3802, Europäische Menschenrechtskonvention und schweizerische Souveränität, 16 December 2004; Samuel Schmid, Interpellation 96.3479, Völkerrecht: Wechsel zum Dualismus, 2 October 1996; Alexander J. Baumann, Motion 96.3482, Systemwechsel für die Einführung von Völkerrecht, 2 October 1996.

349 Federal Council, 201 o Report on International and Domestic Law (n 143), at 2320. 
The irritante alternative ${ }^{350}$ between monism and dualism is often criticized for being simplistic, at odds with reality, and of limited practical significance. ${ }^{351}$ Still, it remains the most accurate and useful way of capturing the range of positions States adopt with regard to the status of international law in their legal order. However, it is important to note that this status hinges on the practice of a given State ${ }^{352}$ rather than on its commitments on paper. It could even be argued that States are initially dualist, before positioning themselves on the monist/dualist spectrum via their organs. Another important point is that the distinction between monism and dualism is a spectrum rather than a dichotomy. ${ }^{353}$ Status is multifaceted: a State may be monist (or dualist) with regard to some sources, ${ }^{354}$ norms, or substantive areas of international law, but not with regard to others. ${ }^{355}$ Its practice may change over time, and the practice of different State organs may be inconsistent. In monist States like Switzerland, courts still have to decide whether or not international law is applicable to a given case. ${ }^{356}$ In this context, they may (consciously or unconsciously) adopt 'blunting rules', as the ILA Study Group on the Principles on

350 Denis Alland, 'Les destins internes du droit international public', Anzilotti et le droit international public : un essai (2nd edn, Pedone 2013) 91.

351 Pierre-Hugues Verdier and Mila Versteeg, 'International Law in National Legal Systems: An Empirical Investigation' (2015) 109 American Journal of International Law 514, 516; ILA, 'Preliminary Report of the ILA Study Group on Principles on the Engagement of Domestic Courts With International Law' (n 61) 6; Charlesworth and others (n 65) 2; Besson, 'Theorizing the Sources of International Law' (n 151) 184. See also Federal Council, 2010 Report on International and Domestic Law (n 143), at 2286.

$35^{2}$ For such a diagnosis: Nijman and Nollkaemper (n 144) 2 f; Mattias Kumm, 'Democratic Constitutionalism Encounters International Law: Terms of Engagement' in Sujit Choudhry (ed), The Migration of Constitutional Ideas (Cambridge University Press 2006) 257.

353 Jean Dhommeaux, 'Monismes et dualismes en droit international des droits de l'homme' (1995) 41 Annuaire français de droit international 447, 448; Andreas L Paulus, 'The Emergence of the International Community and the Divide Between International and Domestic Law' in Janne E Nijman and André Nollkaemper (eds), New Perspectives on the Divide Between National and International Law (Oxford University Press 2007) 229; Charlesworth and others (n 65) 2. See also Federal Council, 2010 Report on International and Domestic Law (n 143), at 2291.

354 Bugalo Maripe, 'Giving Effect to International Human Rights Law in the Domestic Context of Botswana: Dissonance and Incongruity in Judicial Interpretation' (2014) 14 Oxford University Commonwealth Law Journal 251, 258.

355 See the examples in ILA, '(Study Group on) Principles on the Engagement of Domestic Courts With International Law, Final Report: Mapping the Engagement of Domestic Courts With International Law' (n 15) $8 \mathrm{f}$.

356 This preliminary question is reminiscent of what, in us law, has been called Chevron step zero, see Cass R Sunstein, 'Chevron Step Zero' (2006) 92 Virginia Law Review 187. I am indebted to David Scott Louk for drawing my attention to this point. 
the Engagement of Domestic Courts With International Law (hereinafter: 'ILA Study Group on Domestic Courts') calls them, ie, approaches that mitigate the monism of their legal order. ${ }^{357}$

Courts are constrained by the monism of the Swiss State, but they also contribute to shaping it. Monism is often associated with a favorable, 'open' attitude towards international law, ${ }^{358}$ and vice versa. Granted, dualist States, which apply international law in its domesticated form, are more likely to reason as if they were applying domestic law. ${ }^{359}$ On the other hand, their organs might be more willing to apply international law than those of monist jurisdictions. ${ }^{360}$ Much depends, as previously stated, on the practice of the State authorities. ${ }^{361}$ Swiss courts for instance sometimes mention international law even when it has not been invoked by the parties. ${ }^{362}$ They also tend to apply domestic and international law in parallel when their subject matters overlap, ${ }^{363}$ as opposed to courts in other States. ${ }^{364}$ This matches the observation made by Rosalyn Higgins that in monist jurisdictions, international law is more likely to be 'treated as a familiar topic' by the courts. ${ }^{365}$ On the other hand, Swiss courts

357 See infra (n 641). The CEDAW Committee for instance, in its Concluding Observations of 2016 pertaining to Switzerland's 4 th and 5 th periodic reports, criticizes 'the limited awareness of the [CEDAW] Convention and the general recommendations of the Committee as important tools of interpretation within the judiciary', among other actors. See Concluding Observations of the CEDAw Committee, Un Doc CEDAW/C/CHE/CO/4-5, 18 November 2016, para $10 \mathrm{f}$.

$35^{8}$ Gaja (n 338) 61. See also Federal Council, 2010 Report on International and Domestic Law (n 143), 2285 .

359 Richard Gardiner, Treaty Interpretation (2nd edn, Oxford University Press 2016) 143.

36o Federal Council, 2010 Report on International and Domestic Law (n 143), 2286. See also (on dualist South Africa): John Dugard, 'South Africa' in David L Sloss (ed), The Role of Domestic Courts in Treaty Enforcement: A Comparative Study (Cambridge University Press 2009) 475 .

361 Federal Council, 2010 Report on International and Domestic Law (n 143), at 2300. For an example, see Melissa A Waters, 'Creeping Monism: The Judicial Trend Toward Interpretive Incorporation of Human Rights Treaties' (2007) 107 Columbia Law Review 628.

362 BGE 139 I 129, at 3.3 (art. 6(1) ECHR and art. 14 ICESCR). See also BGE 141 I 211 (regarding the ECHR and the ICCPR). See, by contrast, BGE 141 I 97, where the appellant was explicitly relying on art. 6(1) ECHR (at 5) and art. 14 ICCPR (at 6).

363 BGE 140 IV 108, at 6.8 (art. 17(3) Cst. and art. 10 ECHR); BGE 141 II 182, at 6.3.6, 6.4.1 (art. 16(3) Cst. and art. $10 \mathrm{ECHR})$.

364 Eg Veronika Fikfak, "English Courts and the "Internalisation" of the European Convention of Human Rights? Between Theory and Practice' (2015) 5 UK Supreme Court Annual Review 118, 24 ss.

365 Rosalyn Higgins, Problems and Process: International Law and How We Use It (Clarendon Press 1994) 206. 
also refrain from referring to relevant international law in some cases. ${ }^{366}$ In a judgment issued in 2018, for instance, the Swiss Federal Tribunal held that whenever national law did not conflict with international law (in casu with the Swiss-Eu Agreement on the Free Movement of Persons), the lower court 'must first apply the national law, with which it is familiar. ${ }^{367}$ Such statements illustrate the ambivalent role domestic courts often adopt with regard to the interpretation of international law.

\subsubsection{Rank}

The domestic rank of international law pertains to how conflicts between domestic and international law are resolved under domestic law. Although 'one of the great principles of international law, informing the whole system and applying to every branch of it ${ }^{368}$ is that international law, qua law, claims supremacy over domestic law, ${ }^{369}$ including constitutional law, ${ }^{370}$ the rank of international law in the domestic legal order is governed by domestic law.

In Switzerland, the rank of international law is controversial given the constitutional silence on the matter, and due to the high stakes involved for the Swiss State. The issue regularly surfaces in Swiss politics. ${ }^{371}$

366 One example is BGE 136 III 168, at 3.3.4, where the Court applied the Schubert Praxis but did not mention contradictory international law, especially not the principle pacta sunt servanda (art. 26 VCLT). See, by contrast, BGE 139 I 16, at 5.1, where the Court mentioned art. 27 VCLT.

367 BGE 145 V 55 , at 4.1 .

368 Gerald Fitzmaurice, 'The General Principles of International Law Considered From the Standpoint of the Rule of Law' (1957) 92 Recueil des cours de l'Académie de droit international 85 .

369 ICJ, case concerning the Applicability of the Obligation to Arbitrate Under Section 21 of the United Nations Headquarters Agreement of 26 June 1947, advisory opinion, ICJ Reports 1988, 26 April 1988, 12, 34 f, para 57.

370 PCIJ, case concerning the Treatment of Polish Nationals and Other Persons of Polish Origin or Speech in the Danzig Territory, advisory opinion, PCIJ Series A/B No 44, 4 February 1932, 3, at 24; ICJ, case concerning Avena and Other Mexican Nationals (Mexico v. United States), judgment, ICJ Reports 2004, 31 March 2004, 12, at 65, para 139; Anne Peters, 'Supremacy Lost: International Law Meets Domestic Constitutional Law' (20o9) 3 Vienna Online Journal on International Constitutional Law 170, $183 \mathrm{f}$.

371 To mention two recent examples: first, a popular initiative launched by the Swiss People's Party and rejected by Swiss voters in 2018 aimed, inter alia, at establishing the supremacy of the Swiss Constitution over international law, except for mandatory provisions of international law (see <www.admin.ch/ch/d/pore/vi/vis46ot.html >). Second, in June 2015, the Federal Council examined the proposal of the parliamentary group 'FDP. The Liberals' to arbitrate conflicts between Swiss law and international law through a democratic tiebreaker. The group suggested determining the rank of international law in the Swiss legal order based on the respective degrees of democratic legitimacy of 
States often acknowledge the supremacy of international law in principle, ${ }^{372}$ but they seldom accept that international law is supreme over all of domestic law. ${ }^{373}$ As a matter of fact, the Swiss Federal Tribunal has made clear that the Constitution does not endorse an 'unconditional supremacy of international law over domestic law' ${ }^{374}$ Indeed, the Constitution does not settle the issue of rank, except for 'mandatory provisions of international law'375 which constitutional amendments must respect (on this autonomous notion of Swiss law, see infra).

Regardless of how they address the issue of rank, States typically try to avoid conflicts between domestic law and international law in the first place. They do so chiefly through the principle of consistent interpretation, ${ }^{376}$ which expresses a State's adherence to the supremacy of international law. ${ }^{377}$ This principle establishes the presumption that legislatures intend to comply with the State's international obligations. ${ }^{378}$ The Swiss Federal Tribunal first articulated the principle of consistent interpretation in 1968, holding that the federal legislature was to be presumed not to have intended to violate international law. 379 'In case of doubt,' the Court added, 'domestic law is to be interpreted consistently with international law', a principle reflecting 'new trends in France, in the Federal Republic of Germany and in the Netherlands' ${ }^{3} 80$

Despite consistent interpretation, conflicts between international law and Swiss law do arise. To analyze how clashes are handled by the Swiss authorities,

the domestic and international legal norm at stake (FDP.The Liberals Group, Postulat 13.3805, Klares Verhältnis zwischen Völkerrecht und Landesrecht, 24 September 2013). The Federal Council recommended the rejection of the proposal, stating that it was difficult to implement and that conflicts would increasingly be resolved in favor of Swiss law (Federal Council, Klares Verhältnis zwischen Völkerrecht und Landesrecht, Bericht des Bundesrates in Erfüllung des Postulates 13.3805, 12 June 2015, <www.ejpd.admin.ch/ dam/data/bj/staat/gesetzgebung/voelkerrecht/ber-br-d.pdf>, at 2). The parliament followed the Federal Council's recommendation and rejected the proposal.

372 BGer, judgment 1A.161/2000 of 15 June 2000, at $4 \mathrm{f}$ ).

373 André Nollkaemper, 'Rethinking the Supremacy of International Law' (2010) 65 Zeitschrift für öffentliches Recht 65 .

374 BGE 133 V 367 , at 11.1.2.

375 Art. 139(3), 193(4), and 194(2) Cst.

376 For an articulation of this principle in the United States, see Murray v. the Charming Betsey, 6 U.s. 64 (1804).

377 BGE 122 II 234, at 4 e). On States' duty of consistent interpretation, see PCIJ, case concerning the Exchange of Greek and Turkish Populations, advisory opinion, PCIJ Series B No 10, 21 Feburary 1925, 6, at 20.

378 On this point, see The Interpretation of Statutes (n 54) $8 \mathrm{f}$.

379 BGE 94 I 669, at 6 a).

380 Ibid. 
one must distinguish between cantonal law, federal law to the exclusion of socalled 'federal acts' (art. 164 Cst.), federal acts, and constitutional law.

The supremacy of international law is uncontroversial with regard to cantonal law, ${ }^{381}$ since federal law (which includes international law) ${ }^{382}$ trumps cantonal law. ${ }^{383}$ An equally straightforward case is the relationship between international law and federal law, excluding federal acts pursuant to art. 164 Cst. The Constitution states that the courts 'apply the federal acts'. ${ }^{384}$ Apart from federal acts, however, federal law (eg federal ordinances and decrees) gives way to international law.

The relationship between international law and federal acts (as defined by art. 164 Cst.) is without doubt the aspect of the interface between Swiss law and international law that has spilt the most ink. ${ }^{385}$ To handle conflicts between international law and federal acts, the starting point is art. 19o Cst. This provision states that Swiss courts 'apply the federal acts and international law'. Art. 19o entails that courts cannot refrain from applying federal acts and international law (infra, 3.5), but it does not clarify their relationship. Hence, whenever federal acts and international law conflict, Swiss courts are in a typical case of 'double bind': 386 they are bound by two incompatible legal duties.

The Swiss Federal Tribunal's interpretation of art. 19o Cst. has fluctuated over time. In its early case law, the Court often denied the existence of a conflict by presuming that the legislature had not intended to derogate from international law. ${ }^{387}$ Yet in 1933, it held that treaties had 'no other value than any other law regularly voted in and promulgated', and that conflicts were to be resolved by giving preference to the lex posterior. ${ }^{388}$ Later

\footnotetext{
381 BGE 135 II 243, at 3.1.

382 Bernhard Ehrenzeller, Benjamin Schindler, and Rainer J Schweizer (eds), Die schweizerische Bundesverfassung: St. Galler Kommentar (3rd edn, Dike 2014) 1044.

383 Art. 49(1) Cst.

384 Art. 190 Cst.

385 Eg Stefan Schürer, 'Hat die PKк-Rechtsprechung die Schubert-Praxis relativiert? Eine Analyse der PKK-Rechtsprechung und ihrer Auswirkungen auf die Schubert-Praxis' (2015) 116 Schweizerisches Zentralblatt für Staats- und Verwaltungsrecht 115; Marco Sassòli, 'Völkerrecht und Landesrecht: Plädoyer eines Völkerrechtlers für Schubert' in François Bellanger and Jacques de Werra (eds), Genève au confluent du droit interne et du droit international: Mélanges offerts par la Faculté de droit de l'Université de Genève à la Société suisse des juristes à l'occasion du Congrès 2012 (Schulthess 2012).

386 Nollkaemper, National Courts and the International Rule of Law (n 47) 14.

387 Masters (n 331) $100 \mathrm{ff}$. As early as 1884 , in BGE 10 I 583 , at 1, the Court applied a treaty contradicting a prior federal act. For early rulings in which the Court endorses the supremacy of international law, see BGE 42 I 102, at 1; BGE 27 I 52, at 1; BGE 7 I 774, at 4.

388 BGE 59 II 331 , at 4.
} 
rulings ${ }^{389}$ reflect an endorsement of the supremacy of international law and of the idea that whenever a treaty settles an issue, federal acts are not applicable, or only on a subsidiary basis. ${ }^{390}$ Since the early 199os, the Court has deemed the principle of supremacy 'largely undisputed'. ${ }^{391}$ It has emphasized the supremacy of human rights treaties, ${ }^{392}$ but also of treaties in general, ${ }^{393}$ and it considers that supremacy 'follows from the very nature of the international legal norm, which is hierarchically superior to any domestic legal norm'. ${ }^{394}$ It has thereby abandoned its practice of prioritizing the lex posterior, ${ }^{395}$ at least in principle (on the Schubert Praxis, see infra).

The recent practice confirms the Court's ambivalent attitude towards international law. On the one hand, the Court considers that the duty to apply federal acts pursuant to art. 190 Cst. does not prohibit ${ }^{396}$ examining their conformity with constitutional law and with international law, ${ }^{397}$ especially with the $\mathrm{ECHR}^{398}$ (Anwendungsgebot, kein Prüfungsverbot). Hence, the Swiss Federal Tribunal can point to inconsistencies between domestic law and international law, and it can recommend that the legislature amend problematic provisions. ${ }^{399}$ The Court has gone further. It has refrained from applying federal acts conflicting with the ECHR ${ }^{400}$ and with the Swiss-EU Agreement on the Free Movement of Persons, ${ }^{401}$ and it has even hinted that based on the supremacy of international law, it might interpret federal acts contra legem and consistently with international law. ${ }^{402}$ On the other hand, the Court has

389 BGE 123 II 279, at 2 d); BGE 119 V 171, at 4 a); BGE 116 Ib 106, at 1 a); BGE 111 V 2O1, at 2 b); BGE $110 \mathrm{~V} 72$, at 2 b); BGE $109 \mathrm{Ib} 165$ at 7 b); BGE 106 Ib 400, at 5 a); BGE 100 Ia 4O7, at 1 b); BGE 97 I 372, at 1; BGE 91 I 127, at 2; BGE 87 I 134, at 2.

BGE 123 II 134, at 1 a); BGE 122 II 485, at 1; BGE 122 II 140, at 2 (on the so-called 'principle of favor', pursuant to which the Court applies domestic laws if they are more generous regarding mutual legal assistance in criminal matters).

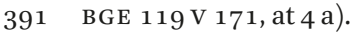

392 BGE 125 II 417 , at $4 \mathrm{~d}$ ).

393 BGE 141 II 436, at 4.1; BGE 139 I 16, at 5.1; BGE 138 II 524, at 5.1. See also (implicitly) BGE 123 II 279, at $2 \mathrm{~d}$ ).

394 BGE $131 \mathrm{~V} 66$, at 3.2.

395 BGE 122 II 485, at 3 a).

396 Some scholars even argue that the Court should be required to bring such inconsistencies to the legislature's attention, see Ehrenzeller, Schindler, and Schweizer (n 382 ) 3053 .

397 BGE 136 I 49, at 3.1.

398 BGE 117 Ib 367 , at 2 e) and f).

399 BGE 136 I 49, at 3.1 (regarding constitutional law); BGE 117 Ib 367 , at 2 e) and f) (regarding international law).

400 BGE 125 II 417, at 4 d); BGE 130 I 312 , at 1.1 and 4.3.1.

401 See especially BGE 133 V 367, at 11 . See also BGE 131 II 352 , at 1.3.2.

402 BGE 136 II 120, at 3.5.3. The case pertained to the Federal Act on Foreign Nationals (SR 142.20) and art. 14 ECHR. 
adopted a hands-off approach when reviewing the conformity of federal acts with the ECHR. ${ }^{403}$ Moreover, the Court maintains a significant exception to the principle of supremacy, namely the so-called Schubert Praxis. ${ }^{404}$

The Schubert Praxis owes its name to the Swiss Federal Tribunal's ruling of 1973 in Schubert contro Commissione cantonale ticinese di ricorso. In this case, the Court held that whenever the legislature willingly derogates from the State's existing international legal obligations, the more recent federal act will trump international law. ${ }^{405}$ The Court allows counter-exceptions to this exception, namely when federal acts are intended to derogate from the $\mathrm{ECHR}^{406}$ or from the non-discrimination principle enshrined in the Swiss-EU Agreement on the Free Movement of Persons. ${ }^{407}$ Another exception mentioned by judges and scholars is jus cogens. ${ }^{408}$ In other cases, however, Schubert applies. A flexible, ad hoc approach to the issue of rank enables judges to take the content of international and domestic legal acts into account when settling conflicts between domestic and international law. ${ }^{409}$ It remains that when Swiss courts apply Schubert, they trigger a violation of international law and, therefore, Switzerland's international responsibility. It is worth noting that the Schubert Praxis has been addressed inconsistently by different chambers of the Swiss Federal Tribunal, ${ }^{410}$ and that some rulings reflect the Court's internal divisions in a way that is unusually candid by Swiss standards. ${ }^{411}$

Another contentious issue relates to conflicts between international law and Swiss constitutional law. Indeed, the Swiss Constitution states that constitutional amendments must respect 'mandatory provisions of international

403 Stefan Schürer, 'Die punktuelle Neutralisierung der EMRK in der Praxis des Bundesgerichts. Zur verkürzten Grundrechtsprüfung bei der Anwendung von Bundesgesetzen' (2016) 117 Schweizerisches Zentralblatt für Staats- und Verwaltungsrecht 171.

404 BGE 136 III 168.

405 BGE $99 \mathrm{Ib} 39$, at 3, 4 .

406 See the references in BGE 139 I 16 , at 5.1.

407 BGE 133 V 367, at 11 and especially 11.6; BGE 142 II 35, at 3.

408 Gilbert Kolly, 'Le Tribunal fédéral suisse' (2016) 3 Les Nouveaux Cahiers du Conseil constitutionnel 47, 52; Sassòli (n 385) $198 \mathrm{f}$.

409 Federal Council, Klares Verhältnis zwischen Völkerrecht und Landesrecht, Bericht des Bundesrates in Erfüllung des Postulates 13.3805, 12 June 2015, <www.ejpd.admin.ch/ $\mathrm{dam} /$ data/bj/staat/gesetzgebung/voelkerrecht/ber-br-d.pdf>.

410 Compare for instance BGE 139 I 16 and BGE 136 III 168.

411 In a decision of 1993, the Court noted that the principle of the supremacy of international law was 'largely undisputed'; the only contrary opinion it mentioned was a law review article by federal judge Hansjörg Seiler, who was not involved in deciding the case and whose opinion the Court deemed 'very much in the minority' (BGE 119 V 171, at 4 a)). 
law',412 but it does not prohibit constitutional enactments from violating nonmandatory international law.

The concept of 'mandatory provisions of international law' is an autonomous concept of Swiss law. Its scope is broader than the (in any case contested and unsharp) international concept of jus cogens pursuant to art. 53 VCLT, as 'Swiss' jus cogens includes non-derogable ECHR and ICCPR rights. ${ }^{413}$ However, the Swiss Constitution does not exclude the possibility that its provisions might violate derogable international human rights. ${ }^{414}$ Although the Federal Council has stated that constitutional law must be interpreted in light of the supremacy of international law, except when 'fundamental principles or the core content of fundamental rights' are at stake, ${ }^{415}$ this one-time statement has not been taken up by Swiss courts. Yet the Swiss Federal Tribunal has sought to mitigate the risk that Switzerland's international responsibility be triggered by constitutional provisions violating non-mandatory international law, especially ECHR guarantees. It has held that constitutional law lacking direct effect must be further specified by the federal legislature, especially regarding its relationship with international law. ${ }^{416}$ In this landmark case pertaining to the popular initiative on the expulsion of foreign criminals, the Court considered that even if a constitutional provision conflicting with the ECHR has direct effect, judges must respect the European Convention when applying the Constitution. ${ }^{417}$ Another sign that the Court seeks to avert international responsibility is that it has preventively given preference to the ECHR by pointing

\footnotetext{
412 Art. 139(3), 193(4), and 194(2) Cst.

413 Federal Council, 2010 Report on International and Domestic Law (n 143), at 2314. See also BGE 133 II 450, at 7.1, where the Swiss Federal Tribunal considers that non-derogability indicates that a norm has the character of jus cogens. See also Federal Council, Botschaft zur Volksinitative 'Schweizer Recht statt fremde Richter (Selbstbestimmungsinitiative)', F G 20175355 , at 5365 .

414 BGE 139 I 16, at 5.2.1.

415 Federal Council, Botschaft zur Genehmigung des Abkommens über den Europäischen Wirtschaftsraum vom 1 8. Mai 1 992, 21 August 1992, FG 1992 IV 1, at 92 ('Grundprinzipien und Kerngehalte der Grundrechte'). The French translation speaks of 'principes fondamentaux ou l'essence même des droits fondamentaux', see the French version of FG 1992 IV 1 , at 87 .

416 BGE 139 I 16 , at 4.3.4.

417 Ibid, at 5.3. The case has been widely discussed in Swiss scholarship and politics. See for instance Giovanni Biaggini, 'Über die Auslegung der Bundesverfassung und ihr Verhältnis zur EMRK' (2013) 114 Schweizerisches Zentralblatt für Staats- und Verwaltungsrecht 316; Astrid Epiney, 'Zur Rolle des Bundesgerichts bei der Verfassungsauslegung: Gedanken zu BGE 139 I 16' Jusletter of 6 October 2014; Yvo Hangartner, 'Bundesgerichtlicher Positionsbezug zum Verhältnis von Bundesverfassung und Völkerrecht' (2013) Aktuelle juristische Praxis / Pratique juridique actuelle 698.
} 
out that under Swiss law, its own decisions may be revised if the ECtHR subsequently rules that they have triggered an ECHR violation. ${ }^{418}$

The question of rank is often contentious, and even more so considering the ambiguity of the Swiss Constitution regarding this subject. Given that the determination of this sensitive issue is conferred to the courts, it is essential that Swiss judges settle it based on the law's interpretative methods, in a predictable, clear, and consistent way.

\subsubsection{Direct Effect}

An international legal act has direct effect (ie, it is 'directly enforceable' or 'selfexecuting') if it can be relied upon by individuals in court. If it lacks direct effect, the act cannot be invoked until the legislature has concretized it. ${ }^{419}$ Direct effect raises the question of which State organ has the legal power to reduce the law's vagueness. ${ }^{420}$ The modalities of direct effect are usually defined by domestic law. ${ }^{421}$ In rare cases, however, direct effect is mandated by international law. ${ }^{422}$

The direct effect of international law is a complex issue that cannot be fully addressed here. ${ }^{423}$ In the following subsections, I set out and evaluate the practice of the Swiss Federal Tribunal regarding the direct effect of written (2.2.3.1) and unwritten (2.2.3.2) international law, before providing some concluding remarks (2.2.3.3). I focus on the case law of the Swiss Federal Tribunal because it is particularly rich and detailed compared to that of other Swiss courts.

\subsubsection{Written International Law}

The Swiss Federal Tribunal has mainly addressed the criteria of direct effect in connection with treaty law. The Court, which deems direct effect 'a question of interpretation, ${ }^{424}$ considers that an international legal act has direct effect

418 Ehrenzeller, Schindler, and Schweizer (n 382$)$ 3051. See art. 122 FA-SFT.

419 Federal Council, 2010 Report on International and Domestic Law (n 143), at 2286.

420 Wüger (n 104) 205.

421 Thomas Buergenthal, 'Self-Executing and Non-Self-Executing Treaties in National and International Law' (1992) 235 Recueil des cours de l'Académie de droit international 303, 396; Forteau (n 108) 99 f. See also BGE 126 I 240, at 2 g).

422 ICJ, LaGrand (Germany v. United States), judgment, ICJ Reports 2001, 27 June 2001, 466, at 494, para 77, regarding art. 36(1) VCCR; PCIJ, case on the Jurisdiction of the Courts of Danzig (Pecuniary Claims of Danzig Railway Officials Who Have Passed Into the Polish Service, Against the Polish Railways Administration), advisory opinion, PCIJ Series B No 15, 3 March 1928, 4, at $17 \mathrm{f}$ (on the Danish-Polish Agreement Concerning Officials (Beamtenabkommen)).

423 Eg Wüger (n 104).

424 BGE 136 I 290, at 2.3.1. See also BGE 121 V 246, at 2 b). 
if three conditions are fulfilled: (i) the act is sufficiently precise to be able to form the basis of a decision, (ii) it pertains to the rights and duties of individuals, and (iii) it is addressed to the law-applying (as opposed to the legislative) authorities. ${ }^{425}$ In some cases, the Court only mentions some of these criteria (eg (i), ${ }^{426}$ or (i) and (iii)), ${ }^{427}$ which is problematic from the perspective of predictability, clarity, and consistency.

Countless rulings have dealt with the direct effect of written international law in the Swiss legal order, and it would be tedious (if at all feasible) to enumerate them. In this subsection, I highlight four particularly controversial and - in my view - problematic cases. They pertain to the ICESCR, the CEDAW, the 1972 Swiss-EEC Free Trade Agreement, and European social security law. I discuss Swiss courts' interpretation of treaties in general in Chapter 7 (infra).

The Swiss Federal Tribunal has often held that the ICESCR does not in principle have direct effect, ${ }^{428}$ with the exception of art. 8(1)(a) ICESCR. ${ }^{429}$ It has considered art. 2(2),, 30 art. $3{ }^{431}$ art. $7\left(\right.$ d),${ }^{432}$ art. $9,{ }^{433}$ art. 11(1), ${ }^{434}$ and art. 13(2) (b) and (c) ICESCR ${ }^{435}$ to lack direct effect, and it has left open the direct effect of art. 8(1)(d) ${ }^{436}$ and art. 13(2)(a) ICESCR. ${ }^{437}$ This contradicts the statement of the UN Committee on Economic, Social and Cultural Rights that a lack of direct effect of some ICESCR provisions ${ }^{438}$ is 'difficult to sustain', and that art. 2(3)(a)

425 BGE 124 III 9o, at 3 a); BGE 120 Ia 1, at 5 b); Christine Kaufmann and Christoph Good, 'Die Anwendbarkeit von ILO-Recht vor Schweizer Gerichten: Potential und Grenzen' (2016) Aktuelle juristische Praxis / Pratique juridique actuelle 647, 647; Ziegler, 'The Application of wTo Law in Switzerland' (n 12) 395.

426 BGE 136 I 290, at 2.3.1.

427 BGE 124 II 293, at 4 b).

428 BGE 136 I 290, at 2.3.1; BGE 135 I 161, at 2.2; BGE 126 I 24O, at 2 c); BGE 125 III 277, at 2 e); BGE 123 II 472, at 4 d); BGE 122 I 101, at 2 a); BGE 122 V 221, at 3 a); BGE 121 V 246, at 2 C); BGE $121 \mathrm{~V} 229$, at 3 a).

429 BGE 122 V 221, at 3 a).

430 Ibid.

431 Ibid.

432 BGE 136 I 290 , at 2.3 .

433 BGE 139 I 257, at 6; BGE 135 I 161, at 2.2.

434 BGE 122 I 101, at 2 a).

435 BGE 120 Ia 1, at $5 \mathrm{~d}$ ).

436 BGE 125 III 277, at 2 e). While the Court considered that there were 'weighty reasons' to consider the provision to have direct effect (at $2 \mathrm{~d}$ ) bb)), it left the question open.

437 BGE 133 I 156 , at 3.6.4.

438 Ie, art. 3, art. 7(a)(i), art. 8, art. 10(3), art. 13(2)(a), (3), and (4), and art. 15(3) ICESCR. See CESCR, General Comment No 3: The Nature of States Parties' Obligations (art. 2, para 1, of the Covenant), 14 December 199o, Un Doc E/1991/23, at para 5. See also CESCR, General Comment No 9: The Domestic Application of the Covenant, 3 December 1998, Un Doc E/C.12/1998/24, at para 10. 
ICESCR requires that States provide effective judicial remedies. ${ }^{439}$ As a matter of fact, the Committee has criticized the Swiss case law for systematically denying direct effect to most ICESCR rights. ${ }^{440}$ Many scholars have criticized the Swiss case law, stating that there are in principle no obstacles to granting social rights direct effect. ${ }^{441}$ It is also worth noting that several domestic socioeconomic rights have direct effect in the Swiss legal order. ${ }^{442}$

A second illustration is provided by the CEDAW, which Switzerland ratified in 1997. The Swiss Federal Tribunal has held that art. 11(1)(e) CEDAw (pursuant to which States must treat women and men equally in terms of social security benefits) lacked direct effect. ${ }^{443}$ It has also cited the Federal Council's statement that most provisions of the CEDAW lacked direct effect. ${ }^{444}$ The Court did not challenge or reexamine the government's sweeping assessment, although the Federal Council had actually left open the possibility that the Swiss Federal Tribunal might grant direct effect to some CEDAW guarantees in the future. ${ }^{445}$

439 CESCR, General Comment No 3 (footnote 438), at para 5. See also CESCR, General Comment No 9 (footnote 438), at para 2 and 3; and para 7, 10 (emphasizing the importance of justiciability), and 14 .

440 CESCR, Consideration of Reports Submitted by States Parties Under Articles 16 and 17 of the Covenant, Concluding Observations: Switzerland, UN Doc E/C.12/CHE/Co/2-3, 26 November 2010, at para 5 .

441 See Maya Hertig Randall and Gregor T Chatton, 'Les droits sociaux en Suisse' in Krzysztof Wojtyczek (ed), Social Rights as Fundamental Rights (Eleven International Publishing 2016) $435 \mathrm{ff}$.

442 Jörg Künzli, Anja Eugster, and Alexander Spring, Die Anerkennung justiziabler Rechte im Bereich der wirtschaftlichen, sozialen und kulturellen Menschenrechte durch das Bundesund das kantonale Recht (Schweizer Kompetenzzentrum für Menschenrechte 2014) 68 f. For an overview: Hertig Randall and Chatton (n 441) $439 \mathrm{ff}$.

443 BGE 139 I 257 , at 6.

444 BGE 137 I 305, at 3.2. See also Federal Council, Botschaft betreffend das Übereinkommen von 1979 zur Beseitigung jeder Form von Diskriminierung der Frau, 23 August 1995, FG 1995 IV 901, at 925; Federal Council, Botschaft über die Genehmigung des Fakultativprotokolls vom 6. Oktober 1999 zum Übereinkommen vom 18. Dezember 1979 zur Beseitigung jeder Form von Diskriminierung der Frau (OP CEDAW), 29 November 2006, FG 2006 9787, at 9802 and 9813 .

445 Federal Council, Botschaft über die Genehmigung des Fakultativprotokolls vom 6. Oktober 1999 zum Übereinkommen vom 18. Dezember 1979 zur Beseitigung jeder Form von Diskriminierung der Frau (OP CEDAW), 29 November 2006, FG 2006 9787, at 9802 (considering that the Swiss Federal Tribunal could accept the direct effect of 'at least some parts' of art. 9 CEDAW and art. 15 CEDAW, and 'potentially also' of art. 7 CEDAW and art. 16 CEDAW); Federal Council, Botschaft betreffend das Übereinkommen von 1979 zur Beseitigung jeder Form von Diskriminierung der Frau, 23 August 1995, FG 1995 IV 901, at $923 \mathrm{ff}$ (noting that the issue of direct effect would have to be considered by the Swiss lawapplying authorities, while stating its own view according to which most provisions of the CEDAW lacked direct effect). 
In another context, with regard to the UN Convention on the Rights of Persons With Disabilities, the Federal Council has stressed that the law-applying authorities must determine direct effect on a case-by-case basis. ${ }^{446}$ This suggests that the Court's deference to the government when interpreting the CEDAW is unwarranted, especially given that the Convention provides that States must provide effective judicial remedies. The Swiss judicial practice has been repeatedly deplored by the CEDAW Committee. ${ }^{447}$ It is worth adding that the Swiss Federal Tribunal has denied the direct effect of other treaties aimed at protecting women. ${ }^{448}$

Another interesting example pertains to the 1972 Free Trade Agreement (FTA) between Switzerland and the EEC. For several decades, and in spite of widespread scholarly criticism, ${ }^{449}$ the Swiss Federal Tribunal declined to grant direct effect to the FTA's provisions. ${ }^{450}$ In 2005 , however, the Court tacitly overruled its previous case law and applied the provisions of the FTA without even mentioning the issue of direct effect. ${ }^{451}$ Daniel Wüger notes that the Federal Council had previously enjoined the Court to overrule its case law, ${ }^{452}$ and that the Federal Appeals Commission for Customs, in a decision of 2001, had contradicted the Court on the very issue that the federal judges addressed in $2005 .{ }^{453}$ In light of these facts, the Court's silence on direct effect

446 Federal Council, Botschaft zur Genehmigung des Übereinkommens vom 13. Dezember 2006 über die Rechte von Menschen mit Behinderungen, 19 December 2012, FG 2013 661, at 674 .

447 Concluding Observations of the CEDAW Committee, Un Doc CEDAW/C/CHE/CO/4-5, 18 November 2016, at para $12 \mathrm{f}$; Concluding Observations of the CEDAW Committee, Un Doc CEDAW/C/CHE/Co/3, 7 August 2009, para 15; Concluding Observations of the CEDAW Committee, UN Doc A/58/38(SUPp), 18 August 2003, para $97 \mathrm{ff}$, at para $106 \mathrm{f}$.

448 The Court has denied direct effect to the International Agreements for the Suppression of the White Slave Traffic of 1904, 1910, 1921, and 1933 (BGE 128 IV 117, at 3 b)), as well as to the provisions of ILO Convention No 111 Concerning Discrimination in Respect of Employment and Occupation (BGE 106 Ib 182, at 4 a)).

449 Christina Schnell, Arbeitnehmerfreizügigkeit in der Schweiz: Ausgewählte rechtliche Aspekte zum Personenfreizügigkeitsabkommen (Schulthess 2010) 86; Thomas Cottier and Erik Evtimov, 'Die sektoriellen Abkommen der Schweiz mit der EG: Anwendung und Rechtsschutz' (2003) 139 Zeitschrift des Bernischen Juristenvereins 77, $101 \mathrm{ff}$.

45O BGE 104 IV 175, at 2 c); BGE 105 II 49, at 3 b); BGE 118 Ib 367, at 6 a).

451 BGE 131 II 271, at 10; Daniel Wüger, 'Bundesgericht wendet Freihandelsabkommen erstmals unmittelbar an - ein Schritt vorwärts, ein Schritt zurück' Jusletter of 4 April 2005.

$45^{2}$ See ibid 43.

453 VPB 66.44, decision of the Federal Appeals Commission for Customs, 29 August 2001, at 5 a) bb). 
is disconcerting and raises the suspicion that the judges caved due to political pressure.

Yet another case where the Court suddenly flipped its approach to direct effect pertains to ILO Convention No 128 and to the European Code of Social Security ${ }^{454}$ In a 'spectacular'455 turnaround, the Swiss Federal Tribunal overruled its (much criticized) ${ }^{456}$ case law based on which these treaties had no direct effect. It granted direct effect to art. 32(1)(e) of the ILo Convention No 128 and art. 68(f) of the European Code of Social Security. 457

In all four examples, the Swiss Federal Tribunal's approach to direct effect fails to convince. Its case law does not appear to follow a predictable, clear, and consistent method.

\subsubsection{Unwritten International Law}

The Swiss Federal Tribunal has barely ever dealt with the issue of whether unwritten international legal acts (ie, CIL and general principles of international law) have direct effect. The Court often mentions the notion of 'direct applicability', but uses it to refer to both direct effect and rank. ${ }^{458}$ This makes it difficult to determine whether the Court is actually considering the issue of direct effect. The Court has stated that non-refoulement is a mandatory principle of international law that, qua CIL, has direct effect in the United States, yet the customary character of the principle was (as is often the case, infra, Chapter 8) only mentioned in passing. ${ }^{459}$ In several decisions, the Court has noted that 'the general principles of international law are directly applicable in Switzerland qua domestic law'460 In most instances, however, it applies unwritten international law without examining its direct effect. ${ }^{461}$ The direct effect of unwritten international law is also sidelined in Swiss legal

\footnotetext{
454 On this case law, see Hertig Randall and Chatton (n 441) $444 \mathrm{f}$.

455 See ibid 445 .

456 Kaufmann and Good (n 425) 653.

457 BGE 119 V 171, at 4 b). See also BGE 120 V 224, at 2. Regarding art. 68(f) of the European Code of Social Security, see also BGE $121 \mathrm{~V} 45$, at 1.

$45^{8}$ BGE $117 \mathrm{Ib} 337$, at 2 a); BGE 125 II 417, at 4 d); BGer, judgment 1A.63/2002 of 9 April 2002, at 2.1; Christian Dominicé, 'Le droit international coutumier dans l'ordre juridique suisse' in Jeanne Belhumeur and Luigi Condorelli (eds), L'ordre juridique international entre tradition et innovation (Graduate Institute Publications 1997) para 8.

459 BGer, judgment 1A.212/2000 of 19 September 2000, at 5 a).

460 BGE $117 \mathrm{Ib} 337$, at 2 a): 'Selon les conceptions en vigueur en Suisse, les principes généraux du droit des gens y sont directement applicables comme droit interne'. See also BGE 125 II 417 , at 4 d); BGer, judgment 1A.63/2002 of 9 April 2002, at 2.1.

461 Wüger (n 104) 284.
} 
scholarship, ${ }^{462}$ as is the method based on which direct effect ought to be determined. ${ }^{463}$

\subsubsection{Concluding Remarks}

To summarize the findings of the previous subsections (2.2.3.1 and 2.2.3.2, supra), the Swiss Federal Tribunal has developed criteria based on which direct effect is determined. However, this test is anything but predictable, clear, and consistent, and it is not applied to unwritten international law. The Court does not appear to refer to art. $31 \mathrm{f} \mathrm{VCLT}$ when determining the direct effect of treaty provisions. A provision's (lack of) direct effect is often asserted without being carefully demonstrated.

Direct effect has implications for the State's duties towards individuals. Therefore, it is politically sensitive, especially regarding economic, social, and cultural rights. ${ }^{464}$ The absence of a predictable, clear, and consistent method of determining direct effect creates the risk that courts will do so based on considerations that are unrelated to the legal act under scrutiny, including political pressure. In reality, courts routinely grant some treaty provisions direct effect, while consistently denying direct effect to others. The axiomatic character of Swiss judicial decisions on direct effect matches Forteau and Nollkaemper's findings that domestic courts seldom explain why an international legal act has or lacks direct effect ${ }^{465}$ and that some rulings on direct effect seem 'fundamentally political'. ${ }^{466}$ It also reflects what Nollkaemper calls the 'duality' of direct effect: domestic courts use direct effect either 'as a powerful sword that can pierce the boundary of the national legal order and protect individual rights', or as a way of 'shield[ing] the national legal order from the effects of international law'467

The lack of a predictable, clear, and consistent method regarding direct effect makes it difficult for individuals to anticipate whether they can invoke an

462 See ibid 283-286; Simonetta Stirling-Zanda, L'application judiciaire du droit international coutumier: étude comparée de la pratique européenne (Schulthess 2000) $15^{2} \mathrm{ff}$. See however Robert Baumann, Der Einfluss des Völkerrechts auf die Gewaltenteilung: am Beispiel Deutschlands, Frankreichs, des Vereinigten Königreichs, der Vereinigten Staaten von Amerika, Schwedens und der Schweiz (Schulthess 2002) 358 ff. See also Dominicé (n $45^{8}$ ) para $16 \mathrm{ff}$.

463 Daniel Wüger for instance, in his study on the direct effect of international law in the Swiss legal order, merely states that the direct effect of cIL should be assessed 'no differently than that of treaty law'. Wüger (n 104) 286.

464 On social rights, see Hertig Randall and Chatton (n 441) 393.

465 Forteau (n 108) $105 \mathrm{f}$.

466 Nollkaemper, 'The Duality of Direct Effect of International Law' (n 59) 109.

467 See ibid 108. 
international legal act in court. It is also problematic when courts clarify other aspects of the relationship between domestic and international law.

\section{Legal Principles of Political Organization}

The legal relationship between the State and other international legal subjects (supra, section 2) is not the only constraint on domestic courts' interpretation of international law. Judges are also limited by legal principles that structure the polity. In Switzerland, these principles include federalism (3.1), linguistic diversity (3.2), the rule of law (3.3), semi-direct democracy (3.4), and the supremacy of the federal legislature (3.5).

\subsection{Federalism}

Most States are unitary States. They are ruled by a central government which decides which powers it wants to delegate to the State's subunits. By contrast, Switzerland - like the United States, Germany, Austria, Belgium, India, and Russia, among other examples - is a federal State, ie, a State composed of sovereign units ${ }^{468}$ ( 26 cantons) which have transferred some of their competences to the federal level (the Confederation). ${ }^{469}$

The Swiss cantons enjoy regulatory autonomy in some respects, while being subjected to federal law in others. On the one hand, the federal government, qua government of enumerated powers, can only exercise the powers delegated to it by the cantons. ${ }^{470}$ Moreover, popular initiatives requesting a partial constitutional revision ${ }^{471}$ and so-called 'mandatory referenda' ${ }^{472}$ require a majority of both the people and the cantons. On the other hand, federal law overrides contrary provisions of cantonal law, ${ }^{473}$ and the cantons must faithfully implement federal law ${ }^{474}$ (which includes international law). ${ }^{475}$

\footnotetext{
468 Art. 3 Cst.

469 Wolfgang Rudolf, 'Federal States', Max Planck Encyclopedia of Public International Law (Online Edition) (Oxford University Press 2011) para 13 <opil.ouplaw.com>.

470 Art. $42(1)$ Cst. The principle of cantonal autonomy enjoys constitutional protection (art. 47 ), and State tasks must be allocated based on the principle of subsidiarity (art. 5a and art. 43a).

471 Art. 138(4) Cst.

472 Art. 140(1) Cst.

473 Art. 49(1) Cst. Eg BGE 141 V 455, at 6.1.

474 Art. 46(1) Cst.

475 Ehrenzeller, Schindler, and Schweizer (n 382$) 1044$.
} 
From the perspective of international responsibility, the acts of federal subunits are attributable to the State. ${ }^{476}$ Besides triggering a violation of their State's existing international obligations, cantonal laws and practices can hinder the ratification of treaties, or make it necessary for the State to add reservations upon ratification. ${ }^{477} \mathrm{I}$ address the structure of the cantonal judiciary in subsection 4.1.2 (infra).

A telling illustration of the challenges cantonal laws create from the perspective of international law (inter alia due to the sensitivity of cantonal prerogatives) is the constitutional ban on face-covering headgear which entered into force in the canton of Ticino on 1 July 2016, after being accepted in a cantonal popular vote in $2013 .{ }^{478}$ One of the effects of the ban is that women are prevented from wearing burqas and niqabs in public. ${ }^{479}$ Besides interfering with cantonal and federal constitutional law, ${ }^{480}$ the ban contradicts Switzerland's international obligations to protect freedom of conscience and religion. ${ }^{481}$

476 Art. 4(1) ARSIWA. Various Us States' repeated violations of foreign nationals' rights under the VCCR, for instance, have triggered the international responsibility of the United States. See ICJ, case concerning Avena and Other Mexican Nationals (Mexico v. United States), judgment, ICJ Reports 2004, 31 March 2004, 12.

477 Switzerland has for instance added a reservation to art. 25(b) ICCPR (which, inter alia, guarantees voting secrecy) to take into account some communal voting procedures and the cantonal 'Landsgemeinden', a secular voting tradition by show of hands still practiced in some cantons. See Federal Council, Botschaft betreffend den Beitritt zur Schweiz zu den beiden internationalen Menschenrechtspakten von 1966 und zu einer Änderung des Bundesrechtspflegegesetzes, 30 January 1991, FG 1991 I 1189, at 1201. This explains why Switzerland has signed, but not ratified Protocol 1 to the ECHR, art. 3 of which guarantees the right to free elections by secret ballot.

478 On this issue, see Samuele Vorpe, 'Das Burkaverbot im Lichte der Religionsfreiheit: Ist die Tessiner kantonale Verfassungsbestimmung über das Gesichtsverhüllungsverbot mit Art. 15 BV vereinbar?' Jusletter of 20 June 2016.

479 Federal Council, Botschaft zur Gewährleistung der geänderten Verfassungen der Kantone Bern, Uri, Solothurn, Basel-Stadt, Basel-Landschaft, Appenzell Ausserrhoden, Appenzell Innerrhoden, Tessin, Waadt und Jura, 12 November 2014, F G 2014 9091, at 9110.

480 Eg art. 15 Cst.

481 Eg art. 9 ECHR and art. 18 ICCPR. See however ECtHR (Grand Chamber), s.A.s. v. France, App No 43835/1 1 (ECHR Reports 2014), 1 July 2014. For an analysis of this decision, see Samantha Besson, 'Human Rights Waivers and the Right to Do Wrong Under the European Convention on Human Rights' in Josep Casadevall and others (eds), Mélanges en l'honneur de / Essays in honour of Dean Spielmann (Wolf Legal Publishers 2015). It is worth noting that in 2014, the AG-BS, in an exceptionally detailed ruling, confirmed the invalidity of an analogous cantonal constitutional initiative on these grounds. See AG-BS, judgment VG 2013.1 of 1 January 2014. The decision is also reported by Andreas Glaser, 'Teil 3: Demokratische Gesetzgebung im Gle ichheitsdilemma: Diskriminierungsverbot und Demokratie - ein Widerspruch?' in Béatrice Ziegler (ed), Ungleichheit(en) und Demokratie (Schulthess 2016) $145 \mathrm{f}$. 
Nonetheless, in March 2015, the proposed amendment of the Constitution of the canton of Ticino obtained the Federal Assembly's seal of approval, the 'federal guarantee. ${ }^{482}$ In September 2018, 66.6\% of voters in the canton of St. Gallen accepted to enshrine a similar ban in their cantonal law. As of June 2019 , a popular vote on a federal ban on face-covering headgear was still pending. ${ }^{483}$ It is worth noting that in October 2018, the Swiss Federal Tribunal partly granted two appeals lodged against the cantonal law implementing the Ticino ban. ${ }^{484}$ The Court ordered that the law be amended so as not to disproportionately harm specific constitutional rights, ie, freedom of assembly, freedom of expression, and economic freedom. While it mentioned the s.A.s. ruling of the ECtHR ${ }^{485}$ the Swiss Federal Tribunal did not examine whether the cantonal law infringed freedom of religion, as the appellants had not invoked this provision.

\section{2 $\quad$ Linguistic Diversity}

From a comparative perspective, Switzerland's linguistic diversity is noteworthy. It impacts Swiss judges' activity in several respects. ${ }^{486}$

Linguistic diversity has been part of Switzerland's cultural identity since the mid-19th century. ${ }^{487}$ It is protected by Swiss constitutional law, which states that Switzerland has four national languages: German, French, Italian, and Romansh. ${ }^{488} \mathrm{~A}$ national language can be used to address the federal authorities, and individuals are entitled to receive an answer in this language. ${ }^{489}$ Switzerland's official languages, on the other hand, ie, German, French, and Italian, ${ }^{490}$ are the

482 Art. 51(2) and art. 172(2) Cst. See Federal Assembly, Bundesbeschluss über die Gewährleistung der geänderten Verfassungen der Kantone Bern, Uri, Solothurn, BaselStadt, Basel-Landschaft, Appenzell Ausserrhoden, Appenzell Innerrhoden, Tessin, Waadt und Jura, 11 March 2015, FG 20152035.

$483<$ <ww.admin.ch/ch/f/pore/vi/vis465.html>.

484 BGE 144 I 281.

485 Ibid, at 3.2.

486 Of course, linguistic diversity also influences the activity of other Swiss officials, eg qua criterion for the election of the members of the Federal Council (art. 175(4) Cst).

487 Georges Lüdi, 'Mehrsprachigkeit', Historisches Lexikon der Schweiz / Dictionnaire historique de la Suisse / Dizionario storico della Svizzera (2013) < www.hls-dhs-dss.ch/textes/d/ D24596.php>.

488 Art. 4 Cst. On linguistic diversity and law in Switzerland, see Niccolò Raselli, 'Langues et justices dans un Etat plurilingue' (2016) Aktuelle juristische Praxis / Pratique juridique actuelle 639 .

489 Art. 6(3) FA-NL.

490 Art. $70(1)$ Cst. 
languages in which federal legislation is published. ${ }^{491}$ All three linguistic versions enjoy the same legal authority. ${ }^{492}$

Linguistic diversity is one criterion for constituting the chambers of the Swiss Federal Tribunal. ${ }^{493}$ Legal briefs submitted to the Court must be written in an official language, ${ }^{494}$ and judicial proceedings take place in one of the four national languages. ${ }^{495}$ This linguistic variety can create inconsistencies in the case law when a legal issue is addressed differently in proceedings conducted in different languages. Judges predominantly working in a specific language (as well as their clerks) might for example be biased in terms of the scholarship they resort to. Language can hence partly explain variations in the way Swiss courts interpret international law. On the other hand, and like judges in other multilingual States (eg Belgium, South Africa, and Canada), Swiss judges are familiar with the interpretive difficulties that may be triggered when legal acts are available in several authoritative linguistic versions. Such linguistic discrepancies are liable to arise, mutatis mutandis, in the context of treay law with different, yet equally authoritative linguistic versions. ${ }^{496}$

\subsection{The Rule of Law}

Art. 5 Cst., entitled 'rule of law', 497 was adopted in the constitutional revision of 1999. It codifies a previously 'unwritten principle of Swiss constitutional law'498 which, according to the Swiss Federal Tribunal, 'impregnate[s] the Swiss constitutional order' ${ }^{\prime} 99$ When referring to this concept, I am addressing the legal principle of the rule of law. I am not looking at the moral principle

\footnotetext{
491 Art. 1O(1) and art. 11 FA-NL.

492 Art. 14 FA-CFLFG.

493 Art. 18(2) FA-SFT.

494 Art. 42(1) FA-SFT.

495 Art. 54(1) FA-SFT. The Act refers to 'official languages' as including Romansh, which contradicts art. 70(1) Cst.

496 For examples of inconsistencies between different linguistic versions of a treaty, see BGE 102 Ia 179, at 3 a) (ECHR); BGE 83 I 16, at 3 (Refugee Convention); BGE 98 II 231, at 4 (Warsaw Convention). See also Marie-Louise Gächter-Alge, Mehrsprachigkeit im Völkervertragsrecht: Von der Ausarbeitung zur Auslegung (Difo-Druck 2011).

497 <www.admin.ch/opc/en/classified-compilation/19995395/20160101000o/101.pdf> (unofficial translation).

498 Federal Council, Botschaft über eine neue Bundesverfassung, 2o November 1996, FG 1997 I 1, at $131 \mathrm{f}$, with reference to BGE 103 Ia 369 (see especially at 6) and BGE 121 I 22 (see at 3 a)).

499 BGE 139 I 16 , at 4.3.2.
} 
of the rule of law, nor am I analyzing how its respective conceptualizations in continental ${ }^{500}$ versus common law ${ }^{501}$ jurisdictions relate. ${ }^{502}$

The Swiss constitutional principle of the rule of law is four-pronged. It provides that State activities 'are based on and limited by law' (para 1), that State action must be proportionate (para 2), that State authorities must act in good faith (para 3) and, finally and importantly, that the Confederation and the cantons must 'respect international law' (para 4). Art. 5(1) and (4) are particularly interesting from the perspective of domestic courts' interpretation of international law. Art. 5(1) Cst. (the principle of legality) ${ }^{503}$ requires that State authorities abide by the law ${ }^{504}$ and that their activity be traceable to a (sufficiently determinate $)^{505}$ legal basis. ${ }^{506}$ It is not a self-standing constitutional right and must be invoked jointly with the principle of the separation of powers, the prohibition of arbitrariness, or specific constitutional rights, for instance. ${ }^{507}$

500 Scholars have used the notion of the 'legal State' to distinguish the continental conception of the rule of law from the rule of law as conceptualized in Anglo-American legal theory. See Stephan Kirste, 'Philosophical Foundations of the Principle of the Legal State (Rechtsstaat) and the Rule of Law' in James R Silkenat, James E Hickey, and Peter D Barenboim (eds), The Legal Doctrines of the Rule of Law and the Legal State (Rechtsstaat) (Springer 2014). Moreover, Swiss scholars differentiate between the Swiss conception of the rule of law (or 'legal State') and the principle of the 'Rechtsstaat' or 'Etat de droit' as articulated in continental political philosophy, see Ehrenzeller, Schindler and Schweizer (n 382) 105. This gives credence to Kirste's observation that the principle of the rule of law/of the legal State branches out into diverse conceptions adopted by different domestic legal orders, based on a given State's history and dominating moral and political philosophy.

501 Raz, 'The Rule of Law and Its Virtue' (n 18); Lamond (n 206); Jeremy Waldron, 'The Rule of Law and the Importance of Procedure' in James Fleming (ed), Getting to the Rule of Law (New York University Press 2011) 5 f; Finnis (n 79) $270 \mathrm{f}$.

502 According to Stephan Kirste, even if the historical, cultural, and ideological contexts of their respective emergence differ, both concepts pursue a 'common goal'. In both cases, their philosophical justification lies in the protection of individual freedom. See Kirste ( $\mathrm{n}_{5} \mathrm{OO}$ ). On the rule of law in international law, see Wohlwend (n 17).

503 BGE 131 II 13, at 6.3.

504 'Vorrang des Rechts', see BGE 91 I 266, at 7; BGE $104 \mathrm{Ib}$ 74, at 5 b) bb). See also BGE $141 \mathrm{~V}$ 557 , at 5.2 (applicable to private individuals exercising a public function, in casu a private company providing compulsory health insurance services).

505 BGE 109 Ia 273, at 4 d). According to the Court, the requirement of legal determinacy aims at preventing that the law-applying authorities make 'unnecessarily substantial value judgments'.

506 'Vorbehalt des Rechts', see BGE 82 I 21, at 3 а); вGE 106 Ia 277, at 3 d). Regarding taxes and fees: BGE 95 I 243, at 4 a); BGE 83 I 81, at 5; BGE 84 I 89, at 2. See however BGE 112 Ia 18, at 3 b). On these two aspects, see Federal Council, Botschaft über eine neue Bundesverfassung, 20 November 1996, FG 1997 I 1, at 132. 
Art. 5(4) (the principle of the international rule of law) ${ }^{508}$ requires that State authorities (including courts) 'respect' (and, though not explicitly stated, apply) ${ }^{509}$ international law. The provision has regularly been invoked by the Swiss Federal Tribunal to highlight the applicability of international law and to justify its supremacy over domestic law. ${ }^{510}$

The constitutional principle of the rule of law is complemented by the prohibition of arbitrariness (art. 9 Cst.) and the principle of good faith (art. 5(3) and 9 Cst.). Arbitrariness, which art. 9 Cst. prohibits, is, according to the Swiss Federal Tribunal, 'the negation of [the] principle [of the rule of law] ${ }^{511}$ Another concretization of the constitutional principle of the rule of law is the right of individuals to have their case reviewed by an independent, impartial court. ${ }^{512}$ All these provisions apply to and constrain Swiss courts' interpretation of international law. It is worth noting that judicial independence, impartiality, and respect for the law are also mandated by Switzerland's international obligations, especially art. 6 ECHR and art. 14 ICCPR. Litigants often invoke them jointly with domestic constitutional law before Swiss courts. ${ }^{513}$

\subsection{Semi-Direct Democracy}

Switzerland is a semi-direct democracy. Its political structure is characterized by elements of direct and representative democracy, both at the cantonal and federal level. It is especially due to its mechanisms of direct democracy - on which I focus in this subsection - that the Swiss political system stands out from a comparative perspective.

On the federal plane, instruments of direct democracy include the popular initiative and the referendum. It is important to stress that the word 'referendum' has a specific meaning under Swiss law that differs from the usage of this term in scholarship outside Switzerland. Popular initiatives give Swiss voters the possibility to request a total or partial revision of the Constitution. ${ }^{514}$ Mandatory and optional referenda require or allow voters to decide certain issues in a popular vote. ${ }^{515}$ Referenda are required, inter alia, in the context of 'accession to organizations for collective security or to supranational

\footnotetext{
508 Ehrenzeller, Schindler, and Schweizer (n 382) 130.

509 See ibid.

510 BGE 139 I 16, at 5.1.

511 ECtHR, Al-Dulimi and Montana Management Inc. v. Switzerland, App No 5809/o8 (ECHR Reports 2016), 21 June 2016, para 145.

512 Art. 30(1) Cst; see also art. 29, 29a, and art. 191c Cst.

513 BGE 137 I 128, at 4; BGE 133 II 450, at 7.3.

514 Art. $138 \mathrm{fCst}$.

515 Art. 140 fCst.
} 
communities'.516 Both the referendum and the popular initiative also exist at the cantonal and subcantonal level. The cantons of Geneva, ${ }^{517}$ Zurich, ${ }^{518}$ BaselStadt, ${ }^{519}$ and Bern ${ }^{520}$ (the case law of which is included in this study, see infra, 4.1.2) all provide for mandatory and optional referenda, popular constitutional initiatives, and popular legislative initiatives, both at the cantonal and at the municipal level. Some of these cantonal instruments are even designed to address issues of international law. ${ }^{521}$

On the one hand, scholars point out that governments can 'lock in' domestic constituencies by entering into treaties from which these constituencies cannot opt out. ${ }^{522}$ On the other hand, recent examples show that referenda, even if they are not binding from the perspective of international law, influence the relationship between the domestic legal order and international law. They can even lead to a renegotiation of (or to a withdrawal from) treaties. The 'Brexit' vote of 23 June 2016 (which, in and of itself, is not even legally binding under UK law) is a case in point. Another example is Swiss voters' decision, on 9 February 2014, to introduce a cap on foreign immigration. ${ }^{523}$ The outcome of this vote conflicts with the Swiss-EU Agreement on the Free Movement of Persons.

Federal popular initiatives increasingly challenge Switzerland's international obligations. Out of the 22 constitutional initiatives accepted by Swiss voters (status as of June 2019), the first of which dates back to 1893, 10 were adopted between 2002 and 2014. ${ }^{524}$ Some of these votes have modified Switzerland's foreign relations in a fundamental way. On 3 March 2002, for instance, Swiss voters approved Switzerland's accession to the UN. ${ }^{525}$ Other votes have created tensions with the State's obligations on the international plane, eg the 2004

\footnotetext{
516 Art. $140(1)(b)$ Cst.

517 Art. 56 ff Cst-GE.

518 Art. $22 \mathrm{ff} \mathrm{Cst-ZH.}$

519 Art. 44 ff Cst-Bs.

520 Art. 55 ff Cst-BE.

521 Art. 23(e) Cst-ZH, for instance, provides that popular initiatives can request that negotiations be started regarding the conclusion, amendment, or termination of an intercantonal or international agreement that is subject to a referendum.

522 Tom Ginsburg, 'Locking in Democracy: Constitutions, Commitment, and International Law' (2006) 38 NYU Journal of International Law and Politics 707, 712.

$523<$ www.admin.ch/ch/f/pore/vi/vis413.html >.

524 See also Council of States, Political Institutions Committee, Requirements as Regards the Validity of Popular Initiatives, Analysis of the Need for Reform, F G 2015 7099, at 7102 . For a similar diagnosis: Cesla Amarelle, 'Législation au forceps et sous la pression du temps à la lumière des initiatives populaires' (2014) 25 LeGes 419.

$<$ www.admin.ch/ch/d/pore/vi/vis292.html >.
} 
vote in favor of the life-long imprisonment of extremely dangerous and nonreformable criminals, ${ }^{, 56}$ or the 2009 ban on the construction of minarets. ${ }^{527}$

One reason for this trend is the extremely deferential review exercised by the Federal Assembly when it examines the substantive validity of constitutional popular initiatives. ${ }^{528}$ Initiatives must be declared invalid 'in whole or in part' if they violate 'the requirements of consistency of form, and of subject matter, or [...] mandatory provisions of international law'.529 Moreover, they cannot be manifestly impracticable. ${ }^{530}$ Since the creation of the constitutional initiative, in 1891, the Federal Assembly declared a popular initiative invalid as a whole only four times, ${ }^{531}$ and only once because it considered that an initiative breached mandatory provisions of international law. ${ }^{532}$ It partially invalidated the 'enforcement initiative' due to its narrow definition of jus cogens. ${ }^{533}$ Several proposals to reform the conditions of the validity of constitutional initiatives have been rejected by the Federal Assembly, including proposals to involve the Swiss Federal Tribunal via advisory opinions. ${ }^{534}$ It is worth noting that in a landmark case decided in April 2019, the Court invalidated a federal

$526<$ www.admin.ch/ch/f/pore/vi/vis294.html $>$. The vote challenges procedural guarantees protected, inter alia, by art. 5(4) ECHR.

$527<$ www.admin.ch/ch/f/pore/vi/vis353.html>. This ban is problematic from the perspective of art. 9 ECHR, among other provisions.

$5_{28}$ Other reasons identified by the Political Institutions Committee of the Council of States include societal tensions, the use of popular initiatives for electoral purposes, and the expansion of the scope of international law binding upon Switzerland. See FG 2015 7099, at 7113 .

529 Art. 139(3) Cst. See also art. 98 FA-FA.

530 Giovanni Biaggini, BV Kommentar: Bundesverfassung der Schweizerischen Eidgenossenschaft (2nd edn, Orell Füssli 2017) $1098 \mathrm{f}$.

531 Ie, the initiative for the 'temporary reduction of military expenditures (weaponry truce)' (1955), the initiative against 'high costs of living and inflation' (1977), and the initiative for 'lower military expenditures and a stronger peace policy' (1995). I am indebted to Camilla Jacquemoud for her input on this topic.

532 In 1996, the Federal Assembly invalidated the initiative for a 'reasonable asylum policy' (Federal Assembly, Federal Decree on the Popular Initiative 'For A Reasonable Asylum Policy', 14 March 1996, FG 1996 I 1355).

533 Federal Assembly, Federal Decree on the Popular Initiative 'For the Enforcement of the Expulsion of Foreign Criminals (Enforcement Initiative)', 20 March 2015, FG 20152701.

534 Council of States, Political Institutions Committee, Requirements as Regards the Validity of Popular Initiatives, Analysis of the Need for Reform, FG 2015 7099, at 7111 . The Federal Assembly and the Federal Council considered that entrusting the Court with such a role would interfere with the separation of powers and introduce constitutional review through the backdoor: FG 2015 7099, at $7111 \mathrm{f}$. See also Federal Council, 2010 Report on International and Domestic Law (n 143), at $2326 \mathrm{ff}$. 
popular vote for the first time in its history, on the grounds that the federal government had provided incorrect information ahead of the vote. ${ }^{535}$

A range of initiatives have explicitly addressed Switzerland's relationship to international law. Examples include the (unsuccessful) initiative requiring a popular vote for the ratification of specific international treaties, ${ }^{536}$ or the (equally unsuccessful) initiative on 'self-determination', which proposed to introduce the supremacy of Swiss constitutional law over international law, except for mandatory provisions of international law. ${ }^{537}$ Some proposals did not gather the required number of signatures to be put to vote, eg the initiative on Swiss neutrality, ${ }^{538}$ the initiative 'for an EU accession moratorium', which demanded that no negotiations on EU accession be conducted for at least ten years, ${ }^{539}$ and yet another initiative requesting that the UDHR be part of the Swiss Constitution. 540

In recent years, political parties and interest groups have used the instruments of direct democracy in ways that have tended to exacerbate the tensions between Swiss law and international law. These tensions also come to the fore in cases brought before Swiss courts. The political sensitivity of these issues makes it even more important that Swiss courts, when they interpret international law, respect its interpretative methods, and that they reason predictably, clearly, and consistently.

\subsection{The Federal Assembly qua 'Supreme Authority of the Confederation'}

An important feature of the Swiss case law is that courts tend to defer to the federal legislature (the Federal Assembly), be it with regard to domestic legal issues or with regard to international law (on this last point, see also infra, 4.2.2.2). Indeed, the Swiss Constitution provides that '[s]ubject to the rights of the People and the Cantons, the Federal Assembly is the supreme authority of the Confederation.'541

The bicameral structure ${ }^{542}$ of the Federal Assembly is inspired by the Us political system. While the National Council ${ }^{543}$ represents the interests of the people (its 200 seats being allocated proportionally to the Swiss cantons'

\footnotetext{
535 BGer, judgment 1C_338/2018 of 10 April 2019 (to be published in the official compendium). See also BGer, judgments 1C_315/2018, 1C_316/2018, 1C_329/2018, 1C_331/ 2018, 1C_335/2018, 1C_337/2018, 1C_339/2018, and 1C_347/2018 of 10 April 2019.

$536<$ www.admin.ch/ch/d/pore/vi/vis363.html $>$.

$537<$ www.admin.ch/ch/d/pore/vi/vis46ot.html>.

$538<$ www.admin.ch/ch/d/pore/vi/vis416.html $>$.

$539<$ www.admin.ch/ch/d/pore/vi/vis395.html $>$.

$540<$ www.admin.ch/ch/d/pore/vi/vis389.html $>$.

541 Art. 148(1) Cst.

542 Art. 148(2) Cst.

543 Art. 149 Cst.
} 
respective populations), the Council of States ${ }^{544}$ encompasses two representatives per canton (and, if applicable, one per half-canton). In addition to adopting federal acts, ${ }^{545}$ the Federal Assembly appoints high officials at the federal level, ${ }^{546}$ and it exercises oversight over the other federal branches. ${ }^{547}$ It is tasked with various further issues (eg taking measures to enforce federal law, and ruling on the validity of popular initiatives), ${ }^{548}$ and it has other residual federal powers not entrusted to any other federal authority. ${ }^{549}$ One major expression of the supremacy of the federal legislature is that federal acts are immune from judicial review ${ }^{550}$ (see also supra, 2.2.2).

Considering this legislative supremacy, Swiss courts usually show deference towards the federal legislature, even when federal acts appear to violate constitutional or international law. This is in stark contrast to courts' activism in other States with constitutional review. Moreover, considerations of democratic legitimacy frequently surface in Swiss rulings. ${ }^{551}$ The Swiss Federal Tribunal has stressed that judicial proceedings be transparent, so that court decisions are subject to a 'democratic check'.552 In a cantonal case pertaining to life-long internment, the President of the District Court of Weinfelden is reported to have stated that the court 'must respect the will of the people and is prohibited from circumventing it with legal tricks and stratagems'.553 As I will emphasize, another manifestation of the importance accorded to democratic legitimacy is that Swiss judges are appointed by the legislature or, in some cases, by the people (infra, 4.2.4).

Democratic legitimacy should be a pivotal concern for Swiss judges given the commitment of the Swiss legal order to democratic principles. This

\footnotetext{
544 Art. 150 Cst.

545 Art. 163 ff Cst.

546 Art. 168(1) Cst.

547 Art. 169 Cst.

548 Art. 173(1) Cst.

549 Art. $173(2)$ Cst.

$55^{\circ}$ Art. 190 Cst.

551 BGE 125 I 119, at 3 d); BGE 125 I 209, at 8 a) (comparing the requirements in terms of impartiality of members of the executive, on the one hand, and of judges, subject to art. 6(1) ECHR, on the other hand); BGE 131 I 333, at 4.3, and BGE 135 I 233, at 2.1 (on the required democratic legitimacy of a municipal legislative act). Constitutional provisions enjoy a high degree of democratic legitimacy due to their enactment procedure, see BGE 133 I 110, at 6.2. Democratic legitimacy is also very often mentioned by the Court in relation to the freedom of vote, see for instance in BGE 140 I 394, at 8.2.

$55^{2}$ BGE 139 I 129, at 3.3.

553 Alex Baur, 'Wenn Juristen das Recht biegen' Die Weltwoche (2010) $<$ www.weltwoche.ch/ausgaben/201O_48/artikel/artikel-2010-48-kommentar-wennjuristen-das-recht-biegen.html>.
} 
commitment is also reflected in some of Switzerland's international obligations, especially in the ECHR. On the other hand, as is well known, democratic legitimacy is not the sole vector of political legitimacy. Democracy requires to be complemented by fundamental rights, some of which are protected by international law. Otherwise, democracy becomes tyrannical. When weighing these potentially conflicting considerations, and given the sensitivity of the issue, judges may be tempted to give in to political pressure. To mitigate this risk, lawful and high-quality judicial reasoning is key (infra, Chapter 5).

\section{The Swiss Judiciary}

The domestic judicial practice of international law cannot be fully grasped without at least a basic understanding of the domestic judicial system under scrutiny. After clarifying the structure of the Swiss judiciary (4.1), I flesh out the most relevant characteristics of Swiss courts' activity from the perspective of the topic of this book (4.2).

\subsection{The Structure of the Swiss Judiciary}

In this subsection, I explain how the Swiss judiciary is structured, both on the federal level (4.1.1) and in the four cantons which I use as case studies (4.1.2). These remarks will help us understand the legal powers and characteristics of various Swiss courts, and why these courts' case law is of interest to a study about international law.

\subsubsection{Federal Courts}

Besides the Swiss Federal Tribunal (4.1.1.1), the Swiss federal judiciary ${ }^{554}$ encompasses the Federal Administrative Court (4.1.1.2), the Federal Criminal Court (4.1.1.3), and the Federal Patent Court. Due to its narrow jurisdiction ${ }^{55}$ and to the marginal relevance of international law to its activity, the Patent Court is left out of this book. The case law of the two other judicial bodies is considered to the extent that it provides insights into international legal issues. Because of the relatively young age of these two bodies, the number of available cases is significantly limited compared to those of the Swiss Federal Tribunal. I do not consider the decisions of appeals commissions (or other quasi-judicial bodies) subsequently replaced by courts in the course of the reform of the judiciary in the early 2000 .

$554<$ www.eidgenoessischegerichte.ch>.

555 Art. 26 FA-FPC. 


\subsubsection{The Swiss Federal Tribunal}

In this book, I often highlight the practice of the Swiss Federal Tribunal, although the decisions of other federal (infra, 4.1.1.2 and 4.1.1.3), cantonal (infra, 4.1.2), and military courts (infra, 4.1.3) are also taken into account (see especially Chapters 7 and 8, infra). I emphasize the case law of the 'supreme judicial authority of the Confederation'556 for several reasons.

First, while all Swiss courts have jurisdiction over international legal issues and are hence liable to trigger the State's international responsibility, the Swiss Federal Tribunal arguably enjoys the highest interpretive authority on the domestic plane. It is also the most authoritative expression of the Swiss practice of international law, at least as regards the interpretation of federal law (a notion which, under Swiss law, includes international law). ${ }^{557}$ This should not detract from the fact that other federal courts (and federal authorities) have the same legal authority to interpret federal law, unless the Swiss Federal Tribunal acts within its powers to review their decisions. Second, the case law of the Swiss Federal Tribunal spans over many decades, contrary to that of other federal courts established in the early 20oos. The Swiss Federal Tribunal's practice is hence particularly suited to an in-depth and representative analysis. A third reason is the breadth of the Court's jurisdiction, which explains the richness of its case law from the perspective of international law. Lastly, from a practical perspective, the Swiss Federal Tribunal's case law is easily accessible, and the Court has the most elaborate search engine of all Swiss courts (see Chapters 7 and 8, infra).

As regards its internal organization, the Court has seven chambers (or divisions). Two of them specialize in public law, two in civil law, one in criminal law, and two in social insurance law. ${ }^{558}$ While international law is particularly likely to be invoked in public law cases, the other chambers are frequently confronted with such issues as well. ${ }^{559}$ The Swiss Federal Tribunal counts 38 full-time judges and 19 part-time judges. Judges are elected by the Federal Assembly (see also infra 4.2 .4$) \cdot{ }^{560}$ Any individual holding the right to vote at the federal level is eligible. ${ }^{561}$ Federal judges serve for a six-year term. ${ }^{562}$ They can

\footnotetext{
556 Art. 188(1) Cst.

557 Ehrenzeller, Schindler, and Schweizer (n 382) 1044.

$55^{8}<$ www.bger.ch/index/federal/federal-inherit-template/federal-gericht/federal-gerichtsabteilungen.htm>.

559 Eg BGE 136 III 168. See also Ammann, 'International Law in Domestic Courts Through an Empirical Lens: The Swiss Federal Tribunal's Practice of International Law in Figures' ( $\left.\mathrm{n}_{5}\right)$.

56o Art. 5(1) FA-SFT, art. 135 FA-FA.

561 Art. 5(2) FA-SFT; art. 136(1) Cst.

562 Art. 9(1) FA-SFT.
} 
be reelected an unlimited number of times, until they reach the age of 68.563 As of June 2019, the Court employed 153 law clerks. ${ }^{564}$

I analyze the Court's jurisdiction with respect to international legal issues in subsection section 4.2.1 (infra).

\subsubsection{The Swiss Federal Administrative Court}

The Swiss Federal Administrative Court (SFAC) started its activity in 2007. It was created as part of the reform of the Swiss judiciary, in 2000. ${ }^{565}$

The Court is divided into six chambers. The third chamber (which handles cases dealing with social insurance and public health), the fourth and fifth chambers (which examine asylum law cases), and the sixth chamber (which deals with cases pertaining to the legislation on foreign nationals) are particularly significant for present purposes. However, all chambers are liable to be confronted with international legal issues. The judges are elected by the Federal Assembly for a six-year term. ${ }^{566}$ At the end of 2018 , the Court counted 76 judges, who were assisted by 238 clerks. ${ }^{567}$

The Court has jurisdiction to review challenges against the decisions of specific federal authorities. ${ }^{568}$ Such decisions sometimes pertain to Swiss foreign relations and to Switzerland's international obligations. Violations of (directly applicable) international legal acts are 'violations of federal law' that can be appealed to the Court. ${ }^{569}$ The Court's case law can be expected to provide insights into the interpretation of international immigration and refugee law, DTAs, and various other bilateral agreements (eg treaties on the recognition and enforcement of foreign judgments, and treaties on mutual legal assistance).

\subsubsection{The Swiss Federal Criminal Court}

The Swiss Federal Criminal Court (SFCC) started its activity in 2004. Like the SFAC, it was established in the context of the reform of the Swiss judiciary. 570

\footnotetext{
563 Art. 9(2) FA-SFT.

$564<$ www.bger.ch/index/federal/federal-inherit-template/federal-richter/federal-richtergerichtsschreiber.htm>.

565 Art. $191 \mathrm{a}(2)$ Cst.

566 Art. 5(1) and art. 9(1) FA-SFAC.

567 See the SFAC's annual report for 2018, <www.bvger.ch/bvger/fr/home/le-tribunaladministratif-federal/rapports-de-gestion.html>.

568 Art. 5 FA-FAP; art. 31 ff FA-SFAC.

569 Art. 49(a) FA-FAP. Eg Elias Hofstetter and Oliver Zibung, 'Art. 49' in Bernhard Waldmann and Philippe Weissenberger (eds), Praxiskommentar zum Bundesgesetz über das Verwaltungsverfahren (Schulthess 2009) 977.

570 On this reform, see Federal Council, Botschaft zur Totalrevision der Bundesrechtspflege, 28 February 2001, FG 2001 4202. The Federal Council notes that the reform takes
} 
The Court is divided into a Criminal Law Chamber and an Appellate Chamber. As of June 2019, the Court was staffed by 20 regular judges ${ }^{571}$ and 10 substitute judges. ${ }^{572}$ The judges are elected by the Federal Assembly for a six-year term. ${ }^{573}$

The SFCC 574 has jurisdiction over several international legal issues, including claims pertaining to international legal assistance ${ }^{575}$ and violations of ICL, IHL, and IHRL. ${ }^{576}$ Its case law can especially provide insights into the interpretation of CIL and into specific substantive areas of international law, such as the law of immunities.

\subsubsection{Selected Cantonal Courts}

As previously mentioned, Switzerland is a federal State that counts 26 cantons (supra, 3.1). The cantons have their own political and legal institutions, including their own judiciary, usually composed of several district courts and of a cantonal supreme court. The decisions of cantonal courts can only be reviewed by the Swiss Federal Tribunal on specific grounds, which include alleged violations of federal and international law. ${ }^{577}$

International legal scholarship dealing with the case law of lower courts is scarce. International lawyers typically focus on the decisions of higher domestic courts. They likely do so because of the greater interpretive authority of these decisions from the perspective of domestic law and, hence, qua expression of the State's practice on international law, ${ }^{578}$ especially when these higher courts overrule the decisions of lower courts on issues of international law. 579

international law into account, 'the implementation of which is increasingly part of the tasks of the Swiss judge' (ibid 4475). By creating an appeal in federal criminal matters, Switzerland was able to withdraw its reservation to art. 14(5) of the ICCPR and to respect the requirements of art. 2 of Protocol 7 to the ECHR. See ibid at 4476 .

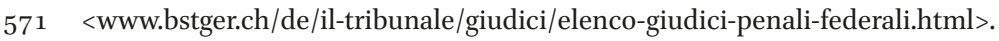

$572<$ <ww.bstger.ch/de/il-tribunale/giudici/elenco-giudici-supplenti.html >.

573 Art. 42(1) and 48(1) FA-OFCA.

$574<$ www.bstger.ch>.

575 Art. 37(2)(a) FA-OFCA.

576 Art. $23 \mathrm{f}$ of the Swiss Criminal Procedure Code of 5 October 2007 (SR 312.o).

577 Art. 95(b) FA-SFT. See also Federal Council, Botschaft zur Totalrevision der Bundesrechtspflege, 28 February 2001, FG 2001 4202, at 4335.

578 ILC, 'Second Report on Identification of Customary International Law by Special Rapporteur Sir Michael Wood' (2014) UN Doc A/CN.4/672 25, para 41 e.

579 One example is the decision of the Greek Supreme Court in Distomo, stating that Germany enjoyed no State immunity for war crimes. The decision was subsequently overruled by the Greek Special Supreme Court in Margellos, a decision followed by other Greek courts. 
Moreover, in some States, scholars note that international law is more often invoked in the higher courts than at the lower levels. ${ }^{580}$

Ignoring lower courts is unjustified, however. First, not all lower court cases dealing with international law reach the highest courts, either because these courts lack jurisdiction or simply because no appeal is lodged. ${ }^{581}$

Second, lower courts play an important role in the implementation of federal law and, hence, of at least some areas of international law, eg IHRL. ${ }^{582}$ A related reason that justifies consulting the case law of lower courts is its quantitative importance compared to that of higher courts: a significant share of a State's 'judicial business' is conducted in the lower courts. ${ }^{583}$

Third, lower courts' case law is of interest when it departs from the established case law in a given State or on the international plane. Although such unorthodox rulings are unlikely to speak authoritatively for the State and, hence, to contribute to State practice on the international plane, they can influence the case law of other courts in later cases. As highlighted by Louis Brandeis, federal subunits are analogous to 'laboratories' where experimentations are (for better or worse) carried out. ${ }^{584}$ As a matter of fact, Simonetta Stirling-Zanda, in her analysis of the determination of CIL in selected European courts, observes that lower courts are often bolder and more progressive' in their reasoning than higher courts. ${ }^{585}$ In Switzerland, for instance, the Administrative Court of the canton of St. Gallen has adopted a particularly international law-friendly approach to the issue of reverse discrimination of

The ICJ concluded that Distomo was of 'limited precendential value', Petersen (n 73) 20. See ICJ, Jurisdictional Immunities of the State (Germany v. Italy; Greece intervening), judgment, ICJ Reports 2012, 3 February 2012, 99, at 134, para 76.

580 Hegde (n 46) 56 .

581 As David Zaring notes with regard to the us judiciary, many scholars focus on the application of international law by the us Supreme Court although ' $[\mathrm{t}]$ he chance that any case will end up in the Supreme Court [...] is today infinitesimal'. David Zaring, 'The Use of Foreign Decisions by Federal Courts: An Empirical Analysis' (2006) 3 Journal of Empirical Legal Studies 297, 305. See also ILC, 'Fifth Report on Identification of Customary International Law by Michael Wood, Special Rapporteur' (n 295) 25 f para 56.

582 Samantha Besson and Eva Maria Belser (eds), La Convention européenne des droits de l'homme et les cantons / Die Europäische Menschenrechtskonvention und die Kantone (Schulthess 2014).

583 See (for the United States): Thomas R Phillips, 'State Supreme Courts: Local Courts in a Global World' (2003) 38 Texas International Law Journal 557, 557 .

584 New State Ice Co. v. Liebmann, 285 U.s. 262 (1932), at 311 . This expression has also been used in Swiss legal scholarship, see for instance Hertig Randall and Chatton (n 441) $405 \mathrm{f}$.

585 Stirling-Zanda $(\mathrm{n} 102) 5$. 
Swiss nationals. ${ }^{586}$ Of course, the highest court of a legal order may set limits on these idiosyncratic interpretations to secure hermeneutic uniformity.

Fourth, although fact-finding is not the focus of this study, ${ }^{587}$ it is important to note that lower courts play an important role in establishing the facts of a case, while higher courts usually review them under narrow circumstances only. 588

Fifth, even when it does not deal with issues of international law, the case law of federal subunits can be of interest because federalism relies on concepts that also exist, mutatis mutandis, at the international level. Examples include the principle of subsidiarity, self-determination, and territorial integrity, and cases pertaining to intercantonal agreements. ${ }^{589}$

In light of these reasons, the present analysis includes the decisions of Swiss cantonal courts to the extent they are relevant from the viewpoint of international law. ${ }^{590}$ For reasons of feasibility, I have focused on the decisions of the highest courts of the cantons of Geneva (4.1.2.1), ${ }^{591}$ Zurich (4.1.2.2), ${ }^{592}$ Basel-Stadt (4.1.2.3), ${ }^{593}$ and Bern (4.1.2.4). ${ }^{594}$ This choice is due to these cantons' demographic and socio-economic importance, but also to the existence of IOs, diplomatic representations, and multinational corporations on their territory. Hence, international law can be expected to have practical relevance in these cantonal jurisdictions. Moreover, most of the recent ${ }^{595}$ case law of the highest courts of these cantons is accessible online in full-text mode, even if

586 The Court has made a teleological interpretation of art. 42(2) FA-FN, inter alia in light of art. 8 and 14 ECHR. See VwGer-SG, decision B 2011/74 of 6 July 2011 (published in GVP 2011:1), at 2.8.

587 Of course, as I will emphasize, the interpretation of many international legal acts requires an empirical inquiry, eg to ascertain State practice and opinio juris (Chapter 8, infra). This specific fact-finding role of courts will be considered.

588 Regarding Switzerland, see art. 97 FA-SFT.

589 In Switzerland, for example, the efforts of some separatist forces in the canton of Bern to join the canton of Jura raise issues in terms of the right to self-determination and of the territorial integrity of the Swiss cantons. See BGE 117 Ia 233, at 4 c).

590 See the list of cantonal courts available at $<$ www.bger.ch/fr/index/press/press-inherittemplate/press-jurisdiction-links/press-jurisdiction-links-gerichte-schweiz.htm>.

$591<$ ge.ch/justice/cour-de-justice $>$.

$592<$ <ww.gerichte-zh.ch/entscheide/entscheide-anzeigen.html>.

$593<$ <ww.rechtsprechung.gerichte-bs.ch>.

$594<w w w . j u s t i c e . b e . c h / j u s t i c e / d e /$ index/entscheide/entscheide_rechtsprechung/ entscheide.html>, <www.openjustitia.apps.be.ch/alfresco/extension/openjustitia/search/ advanced/search.xhtml> (for the OGer-BE and VwGer-BE, respectively).

595 One exception pertains to the decisions of the AG-BS, the availability of which is more limited. 
the searches can be laborious due to the characteristics of some cantonal databases. ${ }^{596}$ The case law of other cantonal and district courts was not surveyed systematically. It was occasionally considered based on case reports published in Swiss legal journals, and based on search results in the Swisslex database. ${ }^{597}$

The following subsections briefly describe the structure and functioning of the aforementioned cantonal courts.

\subsubsection{The Supreme Court of the Canton of Geneva}

The Supreme Court (Cour de justice) is the highest court of the canton of Geneva. It is divided into a Civil Law, a Criminal Law, and a Public Law Division, which all encompass various subdivisions. Recent rulings can be accessed online, ${ }^{598}$ although the dates from which this case law is available vary from one subdivision to the other. ${ }^{599}$

As of June 2019, the Supreme Court was staffed by 37 regular judges. ${ }^{600}$ Judges in the canton of Geneva are elected by the people, ${ }^{601}$ except for labor court judges, who are elected by the cantonal parliament. ${ }^{602}$ Judges serve for a six-year term. ${ }^{603}$

4.1.2.2 The High Court and the Administrative Court of the Canton of Zurich The High Court (Obergericht) is the highest court of the canton of Zurich in civil and criminal matters. ${ }^{604}$ It is divided into two Civil Law and three

596 One example is the Supreme Court of the canton of Geneva, which is divided into various divisions ('cours') and chambers ('chambres'). When performing a keyword search, the search must be conducted separately for each subdivison. Another difficulty is that cantonal databases do not recognize the grammatical variations of a given keyword. $<$ swisslex.ch $>$.

$598<$ ge.ch/justice/dans-la-jurisprudence>.

599 Civil Law Court: Civil Law Chamber (since 2004), Labor Tribunal (since 1998), Tenancy Law Tribunal (since 2007), Chamber of Surveillance in Matters Pertaining to the Commercial Register and to the Land Register, to the Tribunal for the Protection of Children and Adults and to the Former Guardianship Court (since 2007), Chamber of Surveillance in Matters of Debt Collection and Bankruptcy (since 2004), Lawyers' Taxation Commission (since 2007). Criminal Court: Criminal Law Chamber (since 2007), Criminal Appeals Chamber (since 2011), Indictment Chamber (since 2007), Board of Appeals and Revisions (since 2011).

6 oo < ge.ch/justice/sites/default/files/justice/common/listes/magistrats/Magistrats_CJ.pdf>. Figures on the judiciary of the canton of Geneva are also available at <ge.ch/justice/ magistrats $>$.

601 Art. 122(1) Cst-GE.

602 Art. 123(1) Cst-GE.

603 Art. 122(1) Cst-GE.

604 Art. 98(1)(b) and art. 99(1)(e) Cst-ZH. 
Criminal Law Chambers. As of January 2019, the High Court counted 44 regular judges. ${ }^{605}$

The Administrative Court (Verwaltungsgericht) adjudicates disputes in public law matters. ${ }^{606}$ It encompasses four specialized divisions. As of June 2019, it was staffed by 14 regular judges. ${ }^{607}$ All judges are elected by the cantonal parliament and serve for a six-year term. ${ }^{608}$

\subsubsection{The Court of Appeals of the Canton of Basel-Stadt}

The Court of Appeals (Appellationsgericht) is the highest judicial body in the canton of Basel-Stadt in civil, criminal, administrative, and constitutional matters. ${ }^{609}$

As of June 2019, 8 presiding judges and 14 part-time judges were serving on the Court. ${ }^{610}$ Presiding judges are elected by the people. ${ }^{611}$ Part-time judges are chosen by the cantonal parliament. ${ }^{612}$ Judges serve for a six-year term. ${ }^{613}$

\subsubsection{The High Court and the Administrative Court of the Canton of Bern}

The High Court (Obergericht) is the highest court in civil and criminal matters in the canton of Bern. ${ }^{614}$ As of June 2019, it encompassed 22 regular judges. ${ }^{615}$ Regular judges are elected by the cantonal parliament for a six-year term. ${ }^{616}$

The Administrative Court (Verwaltungsgericht) is the highest cantonal court in public law matters. ${ }^{617}$ It is divided into three chambers, which deal with administrative law, social insurance law, and cases in French, respectively (the canton of Bern is bilingual). As of June 2019, 19 regular judges were serving on the Court. ${ }^{618}$ All judges are elected by the cantonal parliament for a six-year term. ${ }^{619}$

605 See the Court's annual report for 2018 , available at <www.gerichte-zh.ch/fileadmin/ user_upload/Dokumente/obergericht/Rechenschaftsberichte/Rechenschaftsbericht_ 2018.pdf $>$.

606 See Art. 1 of the Verwaltungsrechtspflegegesetz of the canton of Zurich of 24 May 1959.

607 <www.vgr.zh.ch/internet/verwaltungsgericht/de/ueber_uns/organisation.html>.

608 Art. 75(1) and 41(2) Cst-ZH.

609 Art. 117(1) Cst-Bs.

$610<$ <ww.appellationsgericht.bs.ch/ueber-das-gericht/gerichtspraesidien.html $>$ and $<w w w$. appellationsgericht.bs.ch/ueber-das-gericht/richterinnen.html>.

611 Art. 44(1)(d) Cst-Bs.

612 Art. 89(1) Cst-Bs.

613 Art. 73(2) Cst-Bs.

614 Art. 98(1)(b) and art. 99(1)(e) Cst-BE.

$615<$ bit.ly/2WgYFfP $>$.

616 Art. 77(1)(d) and (e) Cst-BE.

617 Art. $100(1)$ Cst-BE.

$618<$ bit.ly/2I15O8t $>$.

619 Art. $77(\mathrm{~d})$ and (e) Cst-BE. 


\subsubsection{Military Tribunals}

Besides the decisions of federal and cantonal courts, it is important not to overlook the rulings of military tribunals, which adjudicate disputes pursuant to military law.

In Switzerland, which has a militia army primarily composed of conscripts and volunteers, ${ }^{620}$ the Swiss Criminal Code does not apply to offences subject to military criminal law. ${ }^{621}$ Offences that fall under the Swiss Military Criminal Code (SMCC) can be prosecuted regardless of where they have been committed. ${ }^{622}$ Offences criminalized by the SMCC include violations of the neutrality of Switzerland, ${ }^{623}$ other acts undermining military security, genocide, crimes against humanity, and war crimes. ${ }^{624}$ Decisions of military tribunals are hence liable to provide insights into the interpretation of IHL, ICL, and IHRL. ${ }^{625}$

The Swiss military justice system includes eight military tribunals of first instance, three military courts of appeal and, at the top of the hierarchy, the Military Court of Cassation (MCC). In this book, I primarily consider the decisions of the MCC which have been published on the website of the Swiss authorities since 2006. ${ }^{626}$ Exceptionally, I rely on the decisions of lower military tribunals.

Members of the military justice system must be officers in the army and, in principle, have graduated in law. ${ }^{627}$ Judges serving on the lower military tribunals are appointed by the Federal Council for a four-year term. ${ }^{628}$ Appointments to the MCC are made by the Federal Assembly for a four-year term. ${ }^{629}$

\subsection{Characteristics of Swiss Courts' Interpretative Activity}

In this subsection, my goal is to capture features of Swiss courts' interpretative activity that illuminate the legal context of courts' interpretation of

\footnotetext{
620 Art. 58(1) Cst.

621 Art. 9(1) SCrimC. Art. 3-8 S SMCC clarify which persons are subject to military criminal law.

622 Art. 10(1) SCrimC.

623 Art. 92 f SCrimC.

624 See Chapters 5,6 , and 6 bis, respectively.

625 Eg MCC, N. and Auditor v. Military Appeals Tribunal 1 A, judgment of 27 April 2001, DMC Vol 12 No 21; MCC, Auditor v. Divisional Tribunal 1, judgment of 5 September 1997, DMC Vol 12 No 4. Most relevant rulings are available at <www.icrc.org/applic/ihl/ihl-nat.nsf/ vwLawsByCategorySelected.xsp?xp_countrySelected=CH $>$.

$626<$ ww.oa.admin.ch/de/entscheidungen-militaerjustiz.html>. I excluded the more comprehensive database(<eu.alma.exlibrisgroup.com/view/delivery/41BIG_INST/12329 504630001791\#main-carousel>) for reasons of scope.

627 Art. 2(1) Swiss Military Criminal Procedure Code of 23 March 1979 (SR 322.1).

628 Ibid, art. 7(1) and art. 11(1).

629 Ibid, art. 14(1).
} 
international law. These features include courts' jurisdiction over international legal issues (4.2.1), the extent to which they defer to the other branches (4.2.2), ${ }^{630}$ courts' duties as regards the interpretation of international law (4.2.3), ${ }^{631}$ the procedure pertaining to judges' appointment (4.2.4) and to the drafting of their judgments (4.2.5), the Swiss Federal Tribunal's so-called 'pragmatic methodological pluralism' (4.2.6) and, finally, the legal authority of judicial law in the Swiss legal order (4.2.7).

\subsubsection{Jurisdiction Over International Legal Issues}

The jurisdiction of federal courts other than the Swiss Federal Tribunal has been examined in subsections 4.1.1.2 and 4.1.1.3 (supra). Cantonal laws do not exclude the jurisdiction of cantonal courts over international legal issues. The most detailed laws on Swiss courts' jurisdiction over international legal issues concern the Swiss Federal Tribunal.

While the Swiss Federal Tribunal has general jurisdiction over international legal issues (supra, 4.1.1.1), there are exceptions to this principle. Some issues that may trigger the application of international law are outside the Court's jurisdiction. The Swiss Constitution provides that acts of the Federal Council and of the Federal Assembly cannot in principle ${ }^{632}$ be reviewed by the Swiss Federal Tribunal. ${ }^{633}$ These acts, according to the Court, are 'essentially political decisions' ${ }^{634} \mathrm{~A}$ jurisdictional exclusion also applies to decisions in matters pertaining to foreign relations and is hence likely to involve questions of international law. The Federal Act on the Swiss Federal Tribunal further clarifies the scope of the Court's jurisdiction. ${ }^{635}$

630 See already Besson and Ammann (n 6o) 40.

631 See also ibid 32.

632 See however BGE 125 II 417 , at 4 b) (where the Court reviewed the compatibility of a confiscation order of the Federal Council with art. 6(1) ECHR).

633 Art. 189(4) FA-SFT.

634 BGE 134 V 443, at 3.1.

635 Art. 83 FA-SFT. Appeals in public law matters are inadmissible if they deal with specific foreign relations matters or international legal issues, including decisions affecting the State's external security, neutrality, diplomatic protection, and other issues pertaining to foreign relations, except where international law establishes a right that the issue be adjudicated by a court ((a); see also BGE 132 I 229, at 6.1). Decisions on international administrative assistance are also outside the Court's jurisdiction, with the exception of administrative assistance in fiscal matters ((h); see also art. 84a). Appeals against decisions pertaining to international assistance in criminal matters are admissible only in specific cases and if these cases are deemed 'particularly important', eg when the procedure conducted in a foreign State violates fundamental principles or displays serious flaws (art. 84). 
Swiss courts have not developed an elaborate approach to their own jurisdiction, analogous to the political question doctrine ${ }^{636}$ or the act of State doctrine ${ }^{637}$ of us and U c courts. ${ }^{638}$ These doctrines state the conditions under which courts can review the acts of other domestic authorities or other States. The Swiss Federal Tribunal considers that the notion of 'other matters pertaining to foreign affairs'639 (which are outside its jurisdiction) must be interpreted narrowly. On the other hand, it has noted that the executive enjoys a wide margin of appreciation to defend the State's interests domestically and abroad, and that it has the sole responsibility for decisions taken in this area. ${ }^{640}$

Swiss courts have refused to review some claims by resorting to specific judicial strategies (or 'avoidance doctrines', as Eyal Benvenisti calls them). ${ }^{641}$ One illustration which I have already mentioned concerns the determination of direct effect (supra, 2.2.3) ${ }^{642}$ Another example pertains to the law of immunities. According to the Swiss case law, disputes involving a foreign State are justiciable only if they display a sufficiently tight nexus (a so-called 'Binnenbeziehung') to Switzerland. ${ }^{643}$ The way courts justify their resort to such 'avoidance doctrines' must be scrutinized, as these doctrines might allow them to abdicate from their duty to apply the law. ${ }^{644}$

636 In the United States, see Baker v. Carr, 369 U.s. 186 (1962) and, in foreign affairs, Goldwater v. Carter, 444 U.s. 996 (1979); Zivotofsky v. Clinton, 132 U.s. 1421 (2012). In the United Kingdom, see $R$ (Campaign for Nuclear Disarmament) $v$. Prime Minister and Others, (2002) EWHC 2777 (Admin), cited by Weill (n 61) 76, footnote 41.

637 In the United States, see Underhill v. Hernandez, 168 U.s. 250 (1897); Banco Nacional de Cuba v. Sabbatino, 376 U.s. 398 (1964). On the UK doctrine of non-justiciability, see Buttes Gas \& Oilv. Hammer (No 3), (1982) AC 888 U KHL, 931.

638 (Regarding the political question doctrine) Bernhard Ehrenzeller, 'Politische Fragen vor Verwaltungsgerichten' (2016) 117 Schweizerisches Zentralblatt für Staats- und Verwaltungsrecht 3,16 . On these doctrines, see Weill (n 61) 7 o ff.

639 Art. 83(a) FA-SFT.

640 BGE 137 I 371 , at 1.2 .

641 Benvenisti, 'Judicial Misgivings Regarding the Application of International Law: An Analysis of Attitudes of National Courts' (n 183). On the 'avoiding role' of domestic courts applying IHL, see Weill (n 61) 69 ff. The ILA Study Group on Domestic Courts talks about 'blunting rules'. See ILA, '(Study Group on) Principles on the Engagement of Domestic Courts With International Law, Final Report: Mapping the Engagement of Domestic Courts With International Law' (n 15) $10 \mathrm{ff}$.

642 Ehrenzeller (n 638) 17.

643 BGE 134 III 570, at 2.2.

644 See also Weill (n 61) 7 o. 


\subsubsection{Courts' Relationship With the Other Branches of Government}

In principle, Swiss courts adjudicate international legal issues independently from the other branches. ${ }^{645}$ Yet the Swiss Federal Tribunal frequently takes the back seat and defers to or cites the federal executive (infra, 4.2.2.1) and the federal legislature (infra, 4.2.2.2). It is worth noting at the outset that the fuzzy division of competences between the Federal Assembly and the Federal Council in foreign relations (supra, 2.1.2) creates uncertainty as to their respective powers to apply and interpret (and, hence, to contribute to the formation of) international law. This uncertainty affects the activity of Swiss courts, which often consult the practice of their own State on a given international legal issue (see Chapters 7 and 8, infra).

\subsubsection{The Federal Executive}

The Swiss Federal Tribunal frequently mentions the executive's position on international law and/or its relationship to domestic law. This especially applies to the Federal Department of Foreign Affairs (FDFA) and its Directorate of International Law (DIL).

The Court has particularly often invoked reports, statements, and other documents issued by the DIL on the relationship between domestic and international law. ${ }^{646}$ Other topics on which the Swiss Federal Tribunal has cited the DIL include domestic treaty-making powers, ${ }^{647}$ State succession, ${ }^{648}$ State recognition, ${ }^{649}$ immunities of officials of IOs, ${ }^{650}$ and the service abroad of official documents. ${ }^{651}$ Hence, the Court has mainly cited the Directorate on matters of

645 BGE 132 II 65, at 4.2.3. As the Swiss Federal Tribunal stated in Frigerio with regard to treaty interpretation, 'the practice of the political and administrative authorities does not bind the courts', even if this practice is 'not insignificant for the judge's own opinionforming', вGE 94 I 669, at 5 ; see also BGE $105 \mathrm{Ib} 286$, at 1 b). The latter especially applies when the agreement is primarily applied by other authorities. In such cases, departures from their practice must be justified by 'compelling reasons', BGE 94 I 669, at 5 . See also BGE 112 Ia 148, at 5 b). To emphasize judicial independence, the Court has also stressed that all Swiss authorities have the duty to apply and to respect international law within the limits of their competences, see BGE $117 \mathrm{Ib} 367$, at 2 e). Somewhat ironically, the Court has then cited the FDFA's report on the relationship between domestic and international law.

646 BGE 125 II 417, at 4 d); BGE 120 Ib 36o, at 2 c); BGE 116 IV 262, at 3 b) cc); BGE 123 II 595, at 7 c) and c) hh); BGE $119 \mathrm{~V} 171$, at 4 a).

647 BGE $120 \mathrm{Ib} 360$, at $2 \mathrm{~b})$.

648 BGE 132 II 65, at 3.5.2; BGE 139 V 263, at 5.3 and 6.2; BGE 123 II 511, at 5 d).

649 BGE 13 OII 217 , at 5.3 .

650 BGE $120 \mathrm{~V} 405$, at 3 b).

651 BGE $136 \mathrm{~V} 295$, at 5.1 and 5.2. 
general international law, or with regard to the politically sensitive issue of foreign immunities. At times, the Court has requested the Directorate to provide information deemed relevant to the case. ${ }^{652}$ In some instances, it is unclear whether the DIL's view has been solicited by the Court or one of the parties, or whether the DIL has submitted it proprio motu. ${ }^{653}$ The Directorate actively intervened in several federal court cases on the immunities of States and IOs and their officials. ${ }^{654}$ Empirical work is needed to assess the extent to which the DIL influences the Court in its decision-making, especially in high-profile cases. However, such an endeavor is complicated by the confidential character of judicial work, and by judges' (understandable) reluctance to state that the other branches influence them.

Many rulings of the Swiss Federal Tribunal refer to official documents or statements issued by the FDFA, eg in cases pertaining to the law of immunities, ${ }^{655}$ the State's treaty-making power, ${ }^{656}$ or human rights protection in foreign States. ${ }^{657}$ The FDFA has been asked to provide information by the Swiss Federal Tribunal in some cases, ${ }^{658}$ and the Court has sometimes used its statements to corroborate its own interpretations. ${ }^{659}$ Although it generally emphasizes the separation of powers in foreign affairs, the Swiss Federal Tribunal frequently defers to the FDFA, eg in cases pertaining to privileges and immunities or targeted sanctions. ${ }^{660}$ The Swiss Federal Tribunal also acknowledges

\footnotetext{
652 BGE $111 \mathrm{~V} 65$, at D and $4 \mathrm{~b}$ ).

653 BGE 136 III 575 , at 4.3.1.

654 BGE 136 III 379, at B.b (intervening in favor of the BIS); BGE 134 III 177, at A. (intervening in favor of Russia).

655 BGE 108 III 1O7, at 3; BGE 115 V 11, at 3 a); BGE 134 III 122, at 5.2.

656 BGE 112 Ia 75 , at 4 c).

657 BGE 133 IV 76, at 4.3 (although the Court emphasizes in this case that such reports, even if they must be taken seriously, do not exclude extradition per se, see at 4.4).

658 BGE $110 \mathrm{~V} 145$, at D.

659 BGE $131 \mathrm{~V} \mathrm{174}$, at 3.4 .

66o The Court has considered that the FDFA's refusal to intervene with the BIS to protect the interests of corporations incorporated in Switzerland is an act that lies within the Department's discretionary power, see BGE 137 I 371 , at 1.3.2. It has backed the FDFA in a case pertaining to decisions on targeted sanctions taken by the Department in the aftermath of the Arab Spring on the basis of the power of the executive branch to 'issue ordinances' 'when the interests of the country' are at stake (art. 184(3) Cst.), a notion that the Court interprets in a highly deferential way. See BGE 141 I 20, at 5.1.1 (regarding sanctions taken against Egyptian nationals close to Hosni Mubarak in the aftermath of the Arab spring); BGE 132 I 229, at 10.3 (regarding sanctions against former Congolese dictator Mobutu). The Court has upheld targeted sanctions taken in order to pursue prudential interests, such as the aim of 'preventing that the reputation of Switzerland be tarnished on the international plane' (BGE 132 I 229, at 10.2), and decisions of the FDFA with regard to the privileges and immunities of foreign State representatives (BGE 130 III
} 
the powers of the Department over specific issues, for instance as regards visa requirements. ${ }^{661}$ Exceptionally, however, the Court has explicitly disavowed the FDFA, for example regarding an extradition request ${ }^{662}$ or immunities from execution. ${ }^{663}$

Many of the Swiss Federal Tribunal's rulings with respect to international law refer to the Federal Council. The Court mentions it when the Council acts within its competences with regard to international law (eg concerning State recognition ${ }^{664}$ or foreign relations), ${ }^{665}$ and when it issues interpretive declarations pertaining to specific treaties. ${ }^{666}$ It also mentions the Council to identify the Swiss practice on specific international legal issues. ${ }^{667}$ The Swiss Federal Tribunal frequently cites the dispatch written by the Federal Council prior to the ratification of a treaty by the Federal Assembly. ${ }^{668}$ This can be problematic

430). It has also backed the FDFA's handling of a dispute between the CERN and two cocontractors, rejecting the claim that the Department had failed to respond to the request of the co-contractors (and to intervene with the CERN on their behalf) 'within a reasonable time', as required by art. 6(1) ECHR (BGE 13 I 312 , at 5.4.2.1).

661 BGE 139 I 37 , at 3.2.2.

662 In a suit pertaining to an extradition request from Kazakhstan, the Court, contrary to the FDFA's and to the Federal Office of Justice's statements (BGE 124 II 132, at B.), concluded that the Kazakh authorities had not given sufficient guarantees for extradition to be granted.

663 In BGE 134 III 122, at 5.3.3, the Court rejected the FDFA's statement that immunities from execution can be forfeited only for assets assigned to activities jure gestionis.

664 BGE 139 V 263, at 3 (recognition of Kosovo); BGE 130 II 217, at 5.3 (absence of recognition of Taiwan).

665 BGE 141 II 436, at 4.4.1 (regarding the Swiss Federal Council's decision to adopt the OECD standard regarding automatic exchange of information); BGE 123 II 175, at 2 b) (regarding the collaboration of Switzerland with the ad hoc international criminal tribunals).

666 BGE $118 \mathrm{Ib} 462$, at 2 a) (on the European Convention on Extradition).

667 BGE 112 Ia 75, at 4 c) (on art. 46 VCLT); BGE 123 II 595, at 4 b) (on the principle of good faith in mutual legal assistance cases); BGE 13 O III 430, at 3.4.2 (on the deprivation of diplomatic immunity); BGE 108 II 398, at 3 a) (on the incorporation theory endorsed by Switzerland to determine the nationality of corporations, despite the fact that the Swiss Federal Tribunal's case law slightly differs from this theory, at $3 \mathrm{~b})$ ).

668 BGE 141 II 233, at 4.3.1 (on the Aarhus Convention); BGE 97 I 359, at 6 b) (on a treaty concluded in 1858 between the Swiss Confederation and the Grand Duchy of Baden); BGE 81 II 366, at 1 (on the 1952 Swiss-German Settlement Agreement); BGE 110 Ib 191, at 2 (regarding the New York Convention on the Recognition and Enforcement of Foreign Arbitral Awards); BGE 136 II 241, at 14.2, BGE 133 V 367, at 9.1, and BGE 131 V 39o, at 10.1 (on the Swiss-EU Agreement on the Free Movement of Persons); BGE 110 Ib 208, at 2 b) (on the Refugee Convention); BGE 104 Ia 448, at 7 c), and BGE 99 Ia 78, at 5 a) (on the European Convention on Mutual Assistance in Criminal Matters); BGE 102 II 128, at 3 (on the Hague Convention of 1956 on the Law Applicable to Maintenance Obligations in Respect of Children); BGE 103 Ia 293, at 7 b) (on the ECHR); BGE 108 Ib 525, at 3 (on the Swiss-us Extradition Treaty of 1900). 
if this domestic document is used as a substitute for the (international) travaux préparatoires to the treaty (art. $32 \mathrm{VCLT}$ ). The Court has further deferred to the government on questions of treaty interpretation, ${ }^{669}$ on the interpretation of domestic laws with a nexus to Swiss foreign relations, ${ }^{670}$ and on issues pertaining to the law of immunities ${ }^{671}$ and extradition. ${ }^{672}$ It has backed the Federal Council in high-profile human rights cases ${ }^{673}$ and issues pertaining to the privileges and immunities of $10{ }^{6},{ }^{674}$ as well as in a case of diplomatic treason. ${ }^{675}$ The Court has also cited the Federal Council on matters pertaining to the relationship between domestic and international law ${ }^{676}$ and the definition of jus cogens. ${ }^{677}$ Some rulings even mention the position of individual members of

669 BGE 132 II 65, at 2.3 (on the interpretation of treaties of establishment); BGE 141 II 233, at 4.3 (on the interpretation of the Aarhus Convention); BGE 110 Ib 82, at 4 b) bb) (on the European Convention on Mutual Assistance in Criminal Matters); BGE 123 I 19, at 4 (on the CERD); BGE 84 II 487, at 2 b) (on the Swiss-French Agreement of 1869 on Jurisdiction and the Enforcement of Judgments); BGE $105 \mathrm{Ib} 37$, at 4 c) (on treaties pertaining to the recognition and enforcement of foreign judgments); BGE 103 Ia 517 , at $4 \mathrm{f}$ ) (on ILO Conventions No 100 and 111); BGE 111 V 201, at 3 (on ILO Convention No 128).

670 BGE 126 IV 236, at 4 c) (on art. 267(2) SCrimC, which criminalizes diplomatic treason); $\mathrm{BGE} 120 \mathrm{~V} \mathrm{15}$, at $2 \mathrm{~b}$ ) (on the domestic legal consequences of Switzerland's ratification of the ECHR); BGE 133 V 233, at 3.4 (on the social security status of Swiss UN officials); BGE 109 IV 51, at 2 (on the domestic implementation of the Single Convention of Narcotic Drugs of 1961).

671 BGE 106 Ia 142, at 2 a) (on the right of foreign States to challenge enforcement measures in Swiss courts); BGE 120 V 4O5, at 3 a), and BGE 110 V 145, at 2 a) (on the regime of privileges and immunities of the members of permanent representations to IOS).

672 BGE 99 IV 257 , at $5 \mathrm{~d})$.

673 BGE 125 II 417 ( $P K K$-case); BGE 126 II 145 (on a liability suit pertaining to Switzerland's restrictive asylum policy during World War II; BGer, judgment 2A.784/2006 of 23 January 2008 (Al-Dulimi), and BGE 133 II 450 (Nada), two cases in which the Court backed the executive's implementation of UN targeted sanctions and for which Switzerland was subsequently found to have violated the ECHR by the ECtHR. See ECtHR, Al-Dulimi and Montana Management Inc. v. Switzerland, App No 5809/o8 (ECHR Reports 2016), 21 June 2016; ECtHR, Nada v. Switzerland, App No 10593/o8 (ECHR Reports 2012), 12 September 2012.

674 BGE 13 I I 312.

675 BGE 126 IV 236, at 9.

676 BGE 133 II 450, at 6.1 (on the issue of what international legal norms bind Switzerland); BGE 139 I 16, at 5.2.1 (on the relationship between international law and a subsequently enacted, contradictory contitutional provision); BGE 137 I 305, at 3.2 (on the CEDAW's status in the Swiss legal order; the issue of direct effect was left open by the Court); BGE 93 II 192, at 4 (on the supremacy of a Swiss-French Treaty on Jurisdiction and on the Enforcement of Civil Judgments over Swiss law); BGE 121 V 246, at 2 c) (on the lack of direct effect, in principle, of the provisions of the ICESCR).

677 BGE 133 II 45 o, at $7 \cdot 3$. 
the Federal Council. ${ }^{678}$ Others provide evidence of a close collaboration between the Swiss Federal Tribunal and the federal government. ${ }^{679}$ On rare occasions, the Court explicitly disagrees with the government. ${ }^{680}$ In other cases, the Swiss Federal Tribunal strives to show that it does not contradict the Federal Council's position. ${ }^{681}$

To conclude, even if the Swiss Federal Tribunal's deference towards the federal government in foreign affairs is nowhere near as pronounced as in some other States, ${ }^{682}$ it generally markedly relies on the federal executive. While deference may be warranted when the Federal Council acts within its designated constitutional competences in foreign affairs, it is important to stress that courts must adjudicate disputes with independence and impartiality. This duty is reflected in Swiss law, but also (qua State duty) in international law. ${ }^{683}$ Courts must not shy away from examining the (domestic and international) legality of foreign affairs.

\subsubsection{The Federal Legislature}

As already noted (supra, 2.2.2), art. 190 Cst. states that the Swiss Federal Tribunal must apply federal acts and international law. ${ }^{684}$ One consequence is that federal acts are immune from judicial review, even when they are deemed incompatible with constitutional law or international law. Proposals to introduce constitutional review or to strengthen judicial review have been

678 BGE 123 II 595, at 4 d), where the Court reports the legislative history of the domestic statute at stake and mentions in detail the disagreements between the Federal Council and the legislature; BGE 133 II 97, at 2.2 (mentioning the position of Federal Councillor Christoph Blocher).

679 In Nada, for instance, the Federal Council and the Swiss Federal Tribunal conducted an exchange of views before the Federal Council transferred the complaint of Youssef Nada to the Court. See BGE 133 II 45 o (facts).

68 o One example pertains to an interpretative declaration of the Federal Council to the ECHR, which the Court deemed an invalid reservation, see BGE 118 Ia 473.

681 BGE 82 I 75, at 9 (on the law of immunities).

682 On a past French practice according to which the Conseil d'Etat deferred to the French Ministry of Foreign Affairs on matters of treaty interpretation, and which the ECtHR considered contrary to art. 6(1) ECHR, see ECtHR, Beaumartin v. France, App No 15287/89 (ECHR Reports Series A No 296-B), 24 November 1994, See also United States v. CurtissWright Export Corp., 299 U.s. 304 (1936), where the Us Supreme Court famously held that the President was the 'sole organ of the nation in its external relations'. For an example of utter deference of domestic courts to the executive, see Congyan (n 44).

683 See art. 5(1) and (4) and art. 30(1) Cst., on the one hand, and art. 6 ECHR and art. 14 ICCPR, on the other hand.

684 Art. 190 Cst. 
discussed many times, ${ }^{685}$ but they have always been rejected by the federal parliament. In 2012, the federal government's proposal to abrogate art. $19 \mathrm{o}$ and to introduce a concrete review of federal acts ${ }^{686}$ was once again rejected by the parliament. ${ }^{687}$

While the Swiss Federal Tribunal cannot invalidate federal acts deemed incompatible with international law, the Court can 'invite the legislature' to amend acts deemed problematic. ${ }^{688}$ On its official website, the Court notes that 'controversial judgments can nourish the political debate and eventually lead the parliament to reformulate laws or to incorporate new topics.' ${ }^{689}$ In several cases, the Swiss Federal Tribunal has indeed 'nudged' the federal legislature by pointing out that in case of prolonged legislative inaction, it might intervene in the future and enforce the supremacy of international law. 690

The Court's involvement has been timid, however. One example pertains to reverse discrimination (ie, the discrimination of Swiss citizens compared to EU citizens), which the Swiss Federal Tribunal deems problematic from the perspective of art. 8 and 14 ECHR. In 2010, the Court indicated that it might eventually tackle the issue itself, should the legislature fail to design a remedy compatible with the Constitution and the ECHR 'in a predictable future'.691 In 2015, however, the Court backed down and merely acknowledged the legislature's failure to address the problem, without taking any further steps. ${ }^{692}$

685 Federal Council, Botschaft über eine neue Bundesverfassung, 20 November 1996, FG 1997 I 1, at $505 \mathrm{ff}$; Federal Council, Botschaft zur Neugestaltung des Finanzausgleichs und der Aufgaben zwischen Bund und Kantonen (NFA), 14 November 2001, FG 2002 2291, at 2464 ff; Otto Zwygart, Parliamentary Initiative 99.455, Verfassungsgerichtsbarkeit, 10 October 1999; Heiner Studer, Parliamentary Initiative 05.445, Verfassungsgerichtsbarkeit, 6 October 2005; Vreni Müller-Hemmi, Parliamentary Initiative 07.476, Bundesverfassung massgebend für rechtsanwendende Behörden, 10 October 2007. See also the comprehensive article of Maya Hertig Randall, 'L'internationalisation de la juridiction constitutionnelle : défis et perspectives' (2010) 129 Zeitschrift für Schweizerisches Recht / Revue de droit suisse 221.

686 This proposal was made by the Federal Council namely in order to ensure a congruence between the powers of the Swiss Federal Tribunal and those of the ECtHR, which can assess the compatibility of federal acts with the ECHR; Federal Council, Botschaft über eine neue Bundesverfassung, 20 November 1996, FG 1997 I 1, at 508.

687 One of the arguments raised in parliament was that 'judicial decisions are ultimately not more rational than popular decisions', see Paul Rechsteiner, Council of States, Summer Session 2012, 7th session, 4 June 2012, 8.15 AM (regarding parliamentary initiatives 05.445 and 07.476 ).

688 BGE 136 I 65 , at 3.2 .

$689<$ <ww.bger.ch/index/federal/federal-inherit-template/federal-faq/federal-faq-5.htm>.

69 B BE 125 III 209, at 6 e).

691 BGE 136 II 120, at 3.5.3.

692 BGer, judgment 2C_1071/2014 of 28 May 2015, at 2.1. 
4.2.3 The Duty to 'Apply' and 'Respect' International Law

The Constitution states that Swiss courts 'apply the federal acts and international law'693 and that federal and cantonal authorities 'shall respect international law' ${ }^{694}$ However, Swiss courts have no domestic legal duty to consider international law, unlike the Supreme Court of South Africa, for instance. ${ }^{695}$ They are free, under domestic law, to choose the means they consider appropriate to ensure that Switzerland respects its international obligations. Of course, from the perspective of international law, they may trigger their State's international responsibility, regardless of what domestic law provides. ${ }^{696}$

As previously noted (supra, 3.4), the constitutional popular initiative 'on self-determination' sought to amend art. 190 Cst. and to establish the supremacy of the Swiss Constitution over other laws, including the State's international obligations. The initiative was rejected by Swiss voters on 25 November 2018.

\subsubsection{Judges' Election by the Parliament and Political Affiliation}

Swiss judges are elected by the parliament and, for some of them, by the people. In most cases, they are appointed for a determinate period of time, with the consequence that judges must run for reelection. While this Swiss peculiarity attenuates the counter-majoritarian ${ }^{697}$ traits of judicial decision-making by unelected judges, it also generates difficulties, as I will emphasize. Only a few cantons have mitigated the influence of political parties on judges, ${ }^{698}$ eg Fribourg ${ }^{699}$ and Ticino. ${ }^{700}$

693 Art. 19o Cst.

694 Art. 5(4) Cst. In all these cases, the term 'international law' refers to the sources of international law listed in art. 38 ICJ Statute, see Ehrenzeller, Schindler, and Schweizer (n 382$) 3038$.

695 Art. 39(1) of the Constitution of the Republic of South Africa of 16 December 1996: 'When interpreting the Bill of Rights, a court, tribunal or forum - (a) must promote the values that underlie an open and democratic society based on human dignity, equality and freedom; (b) must consider international law; and (c) may consider foreign law'

696 Art. 27 VCLT, art. 4(1) ARsiwA.

697 Alexander M Bickel, The Least Dangerous Branch: The Supreme Court at the Bar of Politics (Bobbs-Merrill 1962) $16 \mathrm{ff}$.

698 Marco Borghi, 'La mainmise des partis politiques suisses sur l'élection des juges' (2016) Justiz - Justice - Giustizia para 3.

699 Judges are elected for an indeterminate period of time, see art. 121(2) Cst-FR.

700 Prior to the election of judges by the cantonal parliament, a committee of experts issues a recommendation as to the candidates' aptitude, see art. 36(2) Cst-TI. 
The legislature ${ }^{701}$ enjoys substantial leeway when electing federal judges, as the law does not prescribe specific criteria. ${ }^{702}$ Linguistic representativeness is of great relevance to judges' election (on linguistic diversity, see supra, 3.2). The representation of the three official languages was constitutionally required until the revision of the Constitution in $1999,{ }^{703}$ and the Federal Act on the Swiss Federal Tribunal still mandates the federal legislature to take linguistic diversity into account when electing federal judges. ${ }^{704}$ Another important (yet soft) criterion is political representativeness. ${ }^{705}$ Because their (re)election is usually entrusted to the legislature, Swiss judges are, de facto, forced to join a political party, ${ }^{706}$ to which they pay an annual fee of up to $5 \%$ of their yearly salary. ${ }^{707}$ The politicization of Swiss judges has increased in recent years, with fewer judges being members of no political party. While in the 1920s, close to $30 \%$ of judges serving on the Swiss Federal Tribunal had no party affiliation, this percentage is now close to zero. ${ }^{708}$

The parliamentary (or even popular) election of Swiss judges is a peculiarity from a comparative law perspective. ${ }^{709}$ It contrasts with other States where judges are appointed by the President, as is the case with judges of the French Cour de Cassation or Austrian Constitutional Court judges, for instance. It also differs from hybrid modes of selection, like in Italy, where constitutional judges are chosen in part by the parliament, in part by the President, and in part by

701 Federal judges are elected by the Federal Assembly based on a proposal of the Judicial Committee. See <www.parlament.ch/en/organe/committees/other-committees/ committee-jc>.

702 Luc Gonin and Olivier Bigler, 'La sélection des juges fédéraux en Suisse, avec un aperçu cantonal de la situation dans le Canton de Genève' in Lukas Heckendorn Urscheler (ed), Rapports suisses présentés au XIX ${ }^{e}$ Congrès international de droit comparé: Vienne, du 20 juillet au 26 juillet 2014 (Schulthess 2014) $17 \mathrm{f}$.

703 Art. 107(1) of the Swiss Constitution of 29 May 1874.

704 Art. 18(2) FA-SFT.

$705<$ www.bger.ch/index/federal/federal-inherit-template/federal-richter.htm>.

706 See the list at <www.bger.ch/index/federal/federal-inherit-template/federal-richter/ federal-richter-bundesrichter.htm>. On the constitutional problems this 'forced affiliation' creates, see Borghi (n 698) para 38 ff; Nicolas Queloz, 'Compléments récents apportés au droit pénal suisse de la corruption et développements relatifs aux relations entre juges et partis politiques' (2006) Justiz - Justice - Giustizia para $20 \mathrm{ff}$.

707 Tiziano Balmelli, 'Quelques remarques sur l'exigence de réformer les procédures de désignation des juges: la controverse des contributions financières réclamées par les partis' (2006) Justiz - Justice - Giustizia.

708 Adrian Vatter, 'Die Parteifarben der obersten Richterim Wandel' NZZ of 23 September 2013.

709 Benjamin Suter, 'Appointment, Discipline and Removal of Judges: A Comparison Between Swiss and New Zealand Judiciaries' (2015) 46 Victoria University of Wellington Law Review 267; Borghi (n 698) 10. 
the judiciary. Judges' reelection also distinguishes the Swiss judiciary from States where judges in the highest courts have life tenure, ${ }^{710}$ or where reelection is impossible. ${ }^{711}$

Several Swiss judges have defended the Swiss system in their writings. ${ }^{712}$ Yet as many scholars ${ }^{713}$ and even some Swiss magistrates ${ }^{714}$ highlight, this legislative (or popular) mode of selection and, hence, the partisan affiliation of most Swiss judges, the fee they pay their political party, and the fact that they need to run for reelection, all jeopardize courts' independence and impartiality. The importance of judicial independence is reflected in domestic constitutional law and international law. It is also stressed in soft law instruments, ${ }^{715}$ including as regards the judicial interpretation of international law. ${ }^{716}$ These features of the Swiss system have been criticized by the Group of States Against Corruption (GRECO), with little success so far. ${ }^{717}$

Of course, judges decide based on a (more or less consistent) set of beliefs regardless of any formal political affiliation. Moreover, Swiss judges' political affiliation has the merit of being transparent, and it is a way of ensuring that in making their decisions, they remain accountable to the legislature. ${ }^{718}$ However, the absence of separate opinions in the Swiss judiciary (infra, 4.2.5) makes it almost impossible to identify when a judge departs from the party's line. In

710 Eg in the United States, Belgium, France, and the Netherlands.

711 Eg in Germany.

712 Hansjörg Seiler, 'Richter als Parteivertreter' (2006) Justiz - Justice - Giustizia; Peter Albrecht, 'Richter als (politische) Parteivertreter?' (2006) Justiz - Justice - Giustizia.

713 Borghi (n 698); Balmelli (n 707); Queloz (n 706).

714 Niccolò Raselli, 'Richterliche Unabhängigkeit' (2011) Justiz - Justice - Giustizia 6 f; Karl Spühler, 'Der Richter und die Politik' (1994) 130 Zeitschrift des Bernischen Juristenvereins 28 .

715 European Charter on the Statute for Judges of 8-10 July 1998, at 2.1; UN Commission on Human Rights, Civil and Political Rights, Including the Questions of Independence of the Judiciary, Administration of Justice, Impunity, Annex: Bangalore Principles of Judicial Conduct, UN Doc E/CN.4/2003/65, 10 January 2003, Value 1.

716 Institut de droit international, 'The Activities of National Judges and the International Relations of Their State' (1993) <www.justitiaetpace.org/idiE/resolutionsE/1993_mil_ o1_en.PDF>.

717 GRECO, Corruption Prevention in Respect of Members of Parliament, Judges and Prosecutors, Evaluation Report, Switzerland, Fourth Evaluation Round, GrecoEval $4 \operatorname{Rep}(2016)_{5}, 2$ December 2016, $<$ rm.coe.int/CoERMPublicCommonSearchServices/DisplayDCTMContent? documentId=09000016806fceda $>$ (para $95 \mathrm{ff}$ and para 291); GRECO, Corruption Prevention in Respect of Members of Parliament, Judges and Prosecutors, Compliance Report, Switzerland, Fourth Evaluation Round, GrecoRc4(2019)2, 22 March 2019, <rm.coe.int/fourth-evaluationround-corruption-prevention-in-respect-of-members-of/168og4e86o> (para 49-63, para 107, and para 109).

718 Seiler (n 712) para $10 \mathrm{ff}$. 
recent years, studies have sought to establish a correlation between judges' affiliation to a political party and the outcome of their decisions (a correlation which judges themselves deny for understandable reasons). ${ }^{719}$ In October 2016, the Swiss newspaper Tagesanzeiger published the results of an empirical study of 29,263 asylum claims brought before the Federal Administrative Court. The study shows that left-wing judges are up to three times more likely to grant appeals than judges leaning towards the political right. ${ }^{720}$

The increasing number of popular initiatives aimed at limiting Swiss courts' interpretative freedom shows that judicial decision-making is under pressure. ${ }^{721}$ Especially in the area of criminal law, several initiatives express a popular distrust of the judiciary, eg the 2010 vote on the 'expulsion of foreign criminals'722 and its unsuccessful successor, the so-called 'enforcement initiative' of $2016 .{ }^{723}$ Several popular votes have restricted judges' interpretative leeway in cases involving dangerous sexual or violent offenders. ${ }^{724}$ Finally, the initiative on self-determination, rejected in 2018 , sought to limit Swiss courts' interpretative freedom in the arbitration of conflicts between domestic and international law. ${ }^{725}$

Given Swiss judges' mode of selection, it is interesting to take a look at the composition of the Swiss Federal Tribunal. A judge serving on the Swiss Federal Tribunal is typically German-speaking, male, white, and leans towards the right. As of June 2019, out of 38 judges serving on the Swiss Federal Tribunal, 3 spoke Italian as their main language, 12 French, and 23 German. ${ }^{726}$ At the same date, 14 out of the 38 federal judges in office were women. ${ }^{727}$ As of June 2019, 222 out of the 228 former federal judges were men (the first female federal judge, Margrith Bigler-Eggenberger, was elected in 1972 and became a regular federal judge in 1974), and none of the 97 former presidents of the Swiss Federal Tribunal were female. ${ }^{728}$ The

\footnotetext{
719 Borghi (n 698) para 23. See for instance Albrecht (n 712).

720 Rau and Skinner (n 285).

721 FG 2015 7099, at 7102.

$722<$ www.admin.ch/ch/d/pore/vi/vis357.html >.

$723<$ www.admin.ch/ch/d/pore/vi/vis433t.html $>$.

724 Art. 123a, 123b, and 123c Cst., adopted by popular votes in 2004, 2008, and 2014, respectively.

$725<$ www.admin.ch/ch/d/pore/vi/vis46ot.html>.

726 <www.bger.ch/index/federal/federal-inherit-template/federal-richter.htm>.

727 Ibid.

$728<$ www.bger.ch/index/federal/federal-inherit-template/federal-status/federal-richteraltebundesrichter.htm>.
} 
Swiss Federal Tribunal counts few (if any) members of racial or religious minorities. ${ }^{729}$

As of June 2019, the Court counted 9 members of the Socialist Party and 4 members of the Green Party. Thus, one third of the Court (13 out of 38 judges) leaned towards the left. Twenty-five judges were at the center or on the political right: 6 judges were affiliated to the Christian Democratic Party (CVP), 10 to the Swiss People's Party (SVP), 7 to the Free Democratic Party (FDP)/Liberals, 1 to the Conservative Democratic Party (BDP), and 1 to the Green Liberal Party. ${ }^{730}$

\subsubsection{The Absence of Separate Opinions}

Another idiosyncratic feature of the Swiss judiciary (especially compared to common law jurisdictions) is that judgments do not in principle include separate opinions, ie, dissents or concurrences. Thus, Swiss courts' decision-making is more of a black box than that of courts in many other States ${ }^{731}$ and of some international courts. ${ }^{732}$ Contrary to what applies to other jurisdictions, ${ }^{733}$ it is difficult to determine how individual Swiss judges position themselves with regard to particular domestic or international interpretative issues, and how their political affiliation (supra, 4.2.4) affects their decisions. Whenever courts do not deliberate publicly (and they rarely do), one can only analyze the final decision, ie, the aggregation of the preferences of the judges involved in a given case. ${ }^{734}$

729 Bigler and Gonin only mention religious diversity as regards Catholics and Protestants. See Gonin and Bigler (n 702) 18. Vera Rottenberg Liatowitsch, elected in 1994, was the first Jewish judge to serve on the Swiss Federal Tribunal.

730 At the time of writing, it was still unclear whether a retiring svP judge of the Swiss Federal Tribunal's second public law chamber would be replaced by a judge of the same party or, instead, by a CVP judge. The Judicial Committee recommended electing the latter, supposedly to avoid a dominance of the SVP ( 3 instead of 2 judges out of 6 ) in the chamber that addresses conflicts between international law and domestic law. See Fabian Schäfer, 'Angst vor der SvP: Hintergrund der umstrittenen Richterwahl sind die Konflikte zwischen Landes - und Völkerrecht' NZZ of 15June 2019.

731 In common law jurisdictions, courts usually publish concurrences and dissents and disclose the positions of individual judges.

732 Most international courts allow for dissents and concurrences. The CJEU is an exception in this regard.

733 In the United States: David M O'Brien, 'More Smoke Than Fire: the Rehnquist Court's Use of Comparative Judicial Opinions in the Construction of Constitutional Rights' (2006) 22 Journal of Law and Politics 83; Ryan C Black and others, 'Upending a Global Debate: An Empirical Analysis of the U.s. Supreme Court's Use of Transnational Law to Interpret Domestic Doctrine' (2014) 103 Georgetown Law Journal 1.

734 This method is used by Rau and Skinner ( $\mathrm{n} 285$ ). 
The Swiss Federal Tribunal for example takes its decisions by majority vote. $^{735}$ Its rulings only reflect the opinion of the majority, and they do not disclose the breakdown of the votes. ${ }^{736}$ A proposal to introduce dissenting opinions in the Swiss Federal Tribunal was rejected by the Swiss parliament in $1997 .{ }^{737}$ In 2014, both chambers of the parliament agreed to task the Federal Council with preparing a draft version of the Federal Act on the Swiss Federal Tribunal so that rulings can reflect dissenting opinions. ${ }^{738}$ At the time this book was being finalized (June 2019), the government's proposal ${ }^{739}$ had not yet been discussed by the two chambers of the federal parliament. The Swiss Federal Tribunal is opposed to the aforementioned legislative amendment. ${ }^{740}$ When considering whether a legislative amendment is necessary, it is worth noting that it is increasingly rare for the Swiss Federal Tribunal's deliberations to be public. In 2012, for instance, only $0.8 \%$ of all deliberations were. ${ }^{71} \mathrm{In}$ 2018, a public deliberation was held in 48 out of 8,040 cases (ie, in $0.6 \%$ of all cases). ${ }^{742}$ In light of this development, but also due to other reasons, calls for introducing dissenting opinions have become more vocal of late. ${ }^{743}$ At the

\section{Art. 21 FA-SFT.}

736 Art. 122 FA-SFT.

737 Margrith von Felten, Motion 97.3368, Dissenting opinion in Bundesgerichtsentscheiden, 20 June 1997, <www.parlament.ch/fr/ratsbetrieb/suche-curia-vista/geschaeft? AffairId= $19973368>$.

738 National Council, Legal Affairs Committee, Motion 14.3667, Bundesgericht: Dissenting Opinions, 14 August 2014, <www.parlament.ch/de/ratsbetrieb/suche-curia-vista/ geschaeft?AffairId=20143667>.

739 Art. 6o(1 $1^{\text {bis }}$ ) FA-SFT. See FG 2018 4663, at 4664.

740 'Geschäftsbericht des Bundesgerichts 2014' (2015) $11<$ <ww.bger.ch/d/gb_2014_d_ bger.pdf $>$.

741 Michael Baum, 'Minderheitsvoten nur selten publiziert' (2013) 5 plädoyer 64.

$742<$ www.bger.ch/files/live/sites/bger/files/pdf/Publikationen/GB/BGer/de/BGerBGerGB18_d.pdf >.

743 Arnold Marti, 'Offenlegen von Minderheitsmeinungen (“dissenting opinion”): Eine Forderung von Transparenz und Fairness im gerichtlichen Verfahren' (2012) Justiz Justice - Giustizia; Patricia Egli, 'Dissenting Opinions: Abweichende Richtermeinungen im Schweizer Recht' in Franco Lorandi and Daniel Staehelin (eds), Innovatives Recht: Festschrift für Ivo Schwander (Dike 2011); Andreas Glaser and Arthur Brunner, 'Politik in der Defensive: Zwischen Vorrang des FZA und dynamischer Rezeption der EuGH-Rechtsprechung' Jusletter of 18 April 201619 f. On this trend, see Mirjam Baldegger, 'Der wiederkehrende Ruf nach dissenting opinions am Bundesgericht: Wünschbarkeit, Auswirkungen und Ausgestaltung richterlicher Sondervoten in der Schweiz' (2017) 118 Schweizerisches Zentralblatt für Staats- und Verwaltungsrecht 131. For a recent proposal to introduce separate opinions in Swiss courts in public law cases, see Luc Gonin, 'Lopinion dissidente en droit public suisse: une nécessité pratique et théorique' (2017) 136 Zeitschrift für Schweizerisches Recht / Revue de droit suisse 63. For a more cautious view, see Helen Keller and Laura Zimmermann, 'Dissenting Opinions 
cantonal level, only a handful of cantonal judiciaries (Aargau, Geneva, Schaffhausen, Vaud, and Zurich) provide for separate opinions; ${ }^{74}$ this option is rarely used in practice, however. When it is, separate opinions usually take the form of concise dissents. ${ }^{745}$

The fact that disagreements among Swiss judges are not reflected in their opinions (at least as far as federal courts and most cantonal courts are concerned) obscures the truth. Even a judgment adopted unanimously is not monolithic. The 'tyranny of the majority' and the flaws of decisions by majority vote, which are typically criticized in the context of democratic (legislative or popular) decision-making, are equally problematic in the context of judicial decision-making. ${ }^{746}$ Publishing separate opinions can bring to light the conflicting considerations involved in the decisions. It provides helpful information for future cases and strengthens judicial accountability. Together with other factors, the absence of dissents and concurrences also explains the style of Swiss judicial opinions. They are, indeed, impersonal and relatively short, compared to those of English or American courts, for instance. ${ }^{747}$

On the other hand, it is worth noting that by law, pleadings (when applicable), as well as judges' oral deliberations and votes whenever a public deliberation is held, must be public. ${ }^{78}$ This publicity creates difficulties too. It may put additional pressure on judges, especially in politically sensitive cases like those pertaining to the relationship between international law and constitutional

am Bundesgericht: Individuelle Transparenz oder Gefährdung der richterlichen Unabhängigkeit?' (2019) 138 Zeitschrift für Schweizerisches Recht / Revue de droit suisse 137 .

744 Ehrenzeller (n 638) 19 f; Marti (n 743); Gonin (n 743) 65 f.

745 There are exceptions, as Michael Baum points out, inter alia with reference to decision HG110192-O of the Commercial Court (Handelsgericht) of the canton of Zurich of 30 March 2012 (where a 21-page minority opinion is appended to the 8-page-long majority opinion), see Baum (n 741).

746 On this point, see Jeremy Waldron, 'The Core of the Case Against Judicial Review' (2006) 115 Yale Law Journal 1346.

747 Similar to what Gráinne de Búrca notes regarding the CJEU, it could be said about the Swiss Federal Tribunal that the collegiate nature of the judgments and the formalistic style of judicial reasoning is very different from the richly textured, individualized and often colorful opinions of the [us] Supreme Court justices'. Gráinne De Búrca, 'International Law Before the Courts: the EU and the Us Compared' (2015) 55 Virginia Journal of International Law 685,693 . For such a colorful example, see Justice Scalia's dissent in National Federation of Independent Business v. Sebelius, 567 U.s. 519 (2012).

748 Art. 59(1) FA-SFT. 
law. This pressure could increase in the future, given recent trends towards a greater transparency of judicial proceedings. ${ }^{79}$

\subsection{6 'Pragmatic Methodological Pluralism'}

One trademark of the Swiss Federal Tribunal is its 'pragmatic methodological pluralism', as the Court describes its approach to interpretation (see also supra, Chapter 1, section 3). ${ }^{750}$ The Court articulated this conception of judicial interpretation in the $198 \mathrm{os},{ }^{751}$ but used it implicitly in earlier rulings. ${ }^{752}$ It relies on it to interpret domestic statutory law, but also other domestic legal acts, as well as international law. ${ }^{753}$ Pragmatic methodological pluralism is regularly mentioned by other federal ${ }^{754}$ and cantonal ${ }^{755}$ courts, including in the context of international law. ${ }^{756}$ However, the specific implications of the Court's eclectic method for the interpretation of international law have been neglected in Swiss scholarship. ${ }^{757}$ In the following paragraphs, I unpack the notions of

749 In 2014, the National Council rejected the proposal of parliamentarian Martin Schmid to livestream proceedings before the Swiss Federal Tribunal (<www.parlament.ch/fr/ ratsbetrieb/suche-curia-vista/geschaeft?AffairId=2013366o $>$ ). Nonetheless, in April 2016, the Swiss Federal Tribunal started uploading videos of selected public proceedings, see $<$ www.bger.ch/index/press/press-inherit-template/press-mediaplatform/federal-mediaplatformall-meetings.htm >. As of June 2019, nine videos had been uploaded. The videos only cover the Court's final judgment. It remains to be seen how the Court's practice will evolve in this regard.

$75^{\circ}$ Eg BGE 140 II 495 , at 2.3.3.

751 BGE $110 \mathrm{Ib} 1$, at 2 c) Cc); BGE $114 \mathrm{~V} 219$, at 3 a).

$75^{2}$ See BGE 83 I 173, at 4, a decision of 1957 stating that the Court does not exclude any method and 'resorts to the interpretative processes that seem the most proper, in the particular case, to bring out the true meaning of the norm'. See also BGE 59 II 264, at 6: 'Es geht nun nicht an, mit der Beklagten aus formellen Gründen eine "restriktive" Auslegungsmethode zu wählen, die der Sache nicht gerecht wird, sondern es muss der Bestimmung der Sinn beigelegt werden, der mit dem gekennzeichneten Ziel der Gemeinwesen am besten harmoniert (...)'. The Court transposed this method of statutory interpretation to the Constitution in the 1940s: Johannes Reich, Grundsatz der Wirtschaftsfreiheit: Evolution und Dogmatik von Art. 94 Abs. 1 und 4 der Bundesverfassung der Schweizerischen Eidgenossenschaft vom 18. April 1999 (Dike 2011) 33. Besson and Ammann (n 97).

754 SFAC, judgment A-5836/2015 of 26 May 2016, at 7.1.1.

755 VwGer-ZH, 4th chamber, decision VB.2014.00351 of 21 January 2015, at 3.2.2.1.

$75^{6}$ SFAC, judgment C-7063/2008 of 15 May 2009, at 3.3.1.1.

757 Virtually all authors focus on pragmatic methodological pluralism in the context of domestic law. See, among many others, Marc Amstutz, 'Ouroboros: Nachbemerkungen zum pragmatischen Methodenpluralismus' in Peter Gauch, Franz Werro, and Pascal Pichonnaz (eds), Mélanges en l'honneur de Pierre Tercier (Schulthess 2008); Pichonnaz and Vogenauer (n 105); Keshelava (n 105). 
'methodological pluralism' and 'pragmatism', before highlighting the advantages and drawbacks of pragmatic methodological pluralism. I address the implications of this approach for international law in Part 3 (Chapters 5 and following, infra).

By endorsing 'methodological pluralism', the Swiss Federal Tribunal refuses to accept any hierarchy among different interpretative methods. ${ }^{758}$ In the case of written law, the Court acknowledges that textual interpretation is the starting point of interpretation, and that the text should not be departed from lightly. ${ }^{759}$ (On the centrality of textual interpretation, see infra, Chapter 6, 2.1.1.) The four main methods the Court refers to are the literal, systematic, teleological, and historical method. ${ }^{760}$ Except for teleological interpretation, which Friedrich Karl von Savigny considered to be applicable in exceptional cases, ${ }^{761}$ these methods go back to Savigny's 'four elements' doctrine, ${ }^{762}$ later taken up, in a slightly adjusted form, by the Swiss jurist Arthur Meier-Hayoz in his commentary of art. 1 of the Swiss Civil Code. ${ }^{763}$ The four methods are part of the first-year curriculum in Swiss law faculties, and they are mentioned in most Swiss doctrinal analyses of legal reasoning and interpretation. ${ }^{764}$ As I will show (Chapters 5 and 6, infra), these four methods are used in other States as well, even if the terminology is inconsistent, ${ }^{765}$ and even if not all States draw upon Savigny.

The Swiss Federal Tribunal uses 'pragmatism' as a synonym for both resultoriented and anti-theoretical decision-making. This conception of 'pragmatism' must hence be distinguished from other (especially philosophical) ${ }^{766}$

$75^{8}$ BGE 125 II 238, at 5 a); BGE 134 II 308, at 5.2; BGE 139 II 49, at 5.3.1; BGE 140 V 227, at 3.2 .

759 BGE 140 II 495, 2.3.1-2.3.3.

76 O BGE 141 III 155 , at 4.2 .

761 Friedrich Karl von Savigny, System des heutigen römischen Rechts (Bei Veit und Comp 1840) 220.

762 See ibid 212 ff. Eg Reich (n 752) 19 ff. Savigny's elements also included 'logical interpretation', which today is usually associated with systematic interpretation: von Savigny (n 761$) 214$.

763 Reich (n 752) 22.

764 Conformity with international law has sometimes been mentioned as the fifth method, eg BGE 131 II 13, at 8.1. Peter Kunz considers that the four methods should not be supplemented by a fifth, 'comparative law' method: Peter V Kunz, 'Umgang mit internationalem und mit europäischem Recht. Überblick über den "Swiss Approach"' (2012) 23 LeGes $265,270 \mathrm{f}$.

765 Systematic interpretation for instance seems to match what Bradley and Goldsmith refer to as 'structuralism'. See Bradley and Goldsmith (n 171) $41 \mathrm{f}$.

766 On the philosophy of pragmatism, see Hookway (n 117). 
usages of the term. Pragmatism, according to the Court, requires determining which interpretive argument(s) ought to be decisive to ascertain the 'true meaning of the provision, ${ }^{767}$ based on the circumstances of the case. ${ }^{768}$ The Swiss Federal Tribunal has offered various definitions of pragmatic methodological pluralism. Some of them emphasize that the starting point must remain the wording of the provision, ${ }^{769}$ or that the legal act must be interpreted primarily 'out of itself', ie, pursuant to the four aforementioned methods. ${ }^{770}$ Another variation states that the literal meaning can be the basis of the interpretative result only if it yields a just substantive outcome. ${ }^{771}$ Yet other rulings highlight the need for a 'satisfactory result of the ratio legis, ${ }^{772}$ and the importance of avoiding subjective value judgments. ${ }^{73}$ These formulations reveal the evaluative nature of the interpretative process.

This result-oriented approach, and the reluctance to endorse 'grand theories' of judicial decision-making, are rooted in the Swiss polity and its idiosyncrasies. Democratic decision-making (supra, 3.4) and the governmental principle of collegiality require finding solutions that can be accepted inter alia because they are 'workable. ${ }^{774}$ This is not specific to Switzerland, however. In Norway, for instance, courts invoke so-called 'reelle hensyn' ('real considerations'), ${ }^{775}$ through which they openly take policy considerations into account. The importance and ineluctability of such considerations, and lawyers' reluctance to believe in a 'heaven of legal concepts, ${ }^{776}$ have also been emphasized by us judges and legal theorists. ${ }^{777}$ In English administrative law, scholars have

767 BGE 140 II 495, at 2.3.3: 'Ist der Text unklar bzw. nicht restlos klar und bleiben verschiedene Interpretationen möglich, muss nach der wahren Tragweite der Bestimmung gesucht werden.'

768 BGE 138 I 274, at 1.2. As the Court often states, the norm is not reducible to its wording and must be 'understood and specified with regard to the facts of the particular case'. See BGE 141 III 155, at 4.2 .

769 Ie, literal interpretation does enjoy priority unless the wording is not 'absolutely clear', see BGE 131 II 13, at 7.1; BGE $135 \mathrm{~V} 215$, at 7.1; BGE $135 \mathrm{~V} 249$, at 4.1; BGE 139 II 49, at 5.3.1; BGE 139 III 135, at 4.1; BGE 140 II 495, at 2.3.3; BGE 141 III 444, at 2.1.

770 BGE 140 I 305 , at 6.1 .

771 BGE 139 IV 27O, at 2.2; BGE 140 IV 118, at 3.3.

772 BGE 140 I 305 , at 6.1 .

773 BGE 123 II 595, at 4 a); BGE 140 I 305, at 6.2.

774 Art. $177(1)$ Cst.

775 Tor-Inge Harbo, 'The European Economic Area Agreement: A Case of Legal Pluralism' (2009) 78 Nordic Journal of International Law 201, $209 \mathrm{f}$.

776 Felix Cohen, 'Transcendental Nonsense and the Functional Approach' (1935) 35 Columbia Law Review 8og.

777 Holmes (n 22). See also Lochnerv. New York, 198 U.s. 45 (1902), and John Dewey, 'Logical Method and Law' (1924) 33 Philosophical Review 56o. us judges such as Richard 
argued that questions of fact must be distinguished from questions of law based on a 'pragmatic' approach, which they oppose to an 'analytical' one. ${ }^{778}$ An analytical approach, as Timothy Endicott defines it, is 'an attempt to understand', to flesh out the reasons leading to the judicial decision. ${ }^{779}$ Pragmatists dispense with such an analysis. A given interpretation is chosen because it is useful, because it 'will achieve the right outcome.' ${ }^{780}$ Of course, said Norwegian and us doctrines are peculiar to their respective legal, political, and cultural context. Their emphasis on policy considerations starkly differs from the language that characterizes Swiss judicial reasoning. ${ }^{781}$ Still, Swiss courts' 'pragmatism' is arguably not an isolated phenomenon.

Both pluralism and pragmatism can be a virtue, in the sense that judges are not straight-jacketed by a specific interpretative philosophy and pay attention to the characteristics of each case. This is in line with judges' duty to abide by the law and to be independent and impartial. One could argue that judges may make good decisions without adopting an analytical approach in the aforementioned sense, and by sticking to a pragmatic one. ${ }^{782}$ One could also claim that pragmatic methodological pluralism is mandated by international law. Indeed, the methods of treaty interpretation, according to the ILC and to the drafters of the VCLT, must be 'thrown into the crucible, and their interaction [will] give the legally relevant interpretation' ${ }^{783}$

On the other hand, pluralism and especially pragmatism can also be a vice. They create the risk that interpretative arguments are invoked and relied upon opportunistically, depending on the outcome judges seek to achieve, while

Posner have defended a 'pragmatic' view of adjudication: Richard A Posner, 'Pragmatic Adjudication' (1996) 18 Cardozo Law Review 1. The approach of the us Supreme Court to constitutional interpretation has been described as 'pragmatic', see Mark Tushnet, 'Eclecticism in the Service of Pragmatism' in Jeffrey Goldsworthy (ed), Interpreting Constitutions: A Comparative Study (Oxford University Press 2006). Emmanuelle Jouannet opposes the 'rationalism' of French lawyers to the fact that 'culturally, Americans do not like grand, formal, pre-determined structures and distrust the excessive use of legal categories'. See Emmanuelle Jouannet, 'Les visions française et américaine du droit international: cultures juridiques et droit international' in SFDI (ed), Droit international et diversité des cultures juridiques (Pedone 2008) 305.

778 On this issue, see Timothy Endicott, 'Questions of Law' (1998) 114 Law Quarterly Review 292.

779 See ibid $308 \mathrm{f}$.

780 See ibid 315 . See also Walter (n 118$)$.

781 BGE $98 \mathrm{Ib} 385$, at 2 a); BGer, judgment 4A_214/2013 of 5 August 2013, at 5.2.2.

782 This argument is mentioned by Endicott ( $\mathrm{n} 778) 309$.

783 ILC, 'Draft Articles on the Law of Treaties With Commentaries' (1966) II Yearbook of the International Law Commission 220. 
contrary arguments are ignored. The anti-theoretical flavor of pragmatism may also legitimize a lack of judicial candor, and it dispenses judges from giving articulate reasons for their decisions. As a matter of fact, Swiss judges tend to cite the arguments that support the interpretative result reached by the ruling and, therefore, to consider only one part of the argumentative picture. Pragmatic methodological pluralism can encourage a form of lawlessness, thereby undermining judges' duty to obey the law. Moreover, as I will argue in more detail, pragmatic methodological pluralism may be unsuited to the interpretation of international law if it disregards the characteristics of it sources and its interpretative methods (Chapters 5 and following).

References to pragmatism often appear in the practice of other Swiss authorities as well. Pragmatism is frequently invoked in the context of Swiss foreign relations. ${ }^{784}$ Moreover, the consensual nature of Swiss politics ${ }^{785}$ requires finding workable solutions. Finally, 'pragmatism' also influences Swiss scholarship (supra, Chapter 1, 2.5), which rarely overtly criticizes the Swiss Federal Tribunal's interpretative approach. In the United States, judges and scholars often endorse a distinctive interpretative philosophy, ${ }^{786}$ and they have offered elaborate theoretical accounts of legal and judicial interpretation. ${ }^{787}$ Swiss judges and scholars, by contrast, do not usually advocate the superiority of one interpretative method, nor do they seek to theorize their interpretative approach. ${ }^{788}$ Swiss constitutional legal scholars describe their field as 'skeptical towards overly abstract concepts, ${ }^{789}$ but they barely dwell on the reasons for this skepticism. Few scholars depart from this path to analyze the Court's interpretative methods. ${ }^{790}$ The handful of authors who have more openly criticized the Swiss Federal Tribunal's 'pragmatic methodological pluralism' have called it a 'method without method', ${ }^{791}$ a 'principled unprincipledness, ${ }^{792}$ a

784 FDFA, Swiss Foreign Policy Strategy $2016-19$ (n 300).

785 The Federal Council for instance is composed of seven ministers belonging to different representative political parties.

786 Examples include originalism, living constitutionalism, or political process theory.

787 See for instance Richard Fallon, 'A Constructivist Coherence Account of Constitutional Interpretation' (1987) 100 Harvard Law Review 1189.

788 Walter (n 118 ).

789 Ehrenzeller, Schindler, and Schweizer (n 382) 106.

790 For innovative approaches, however, see Amstutz (n 757); Marc Amstutz, 'Der Text des Gesetzes: Genealogie und Evolution von Art. 1 ZGB' (2007) 126 Zeitschrift für Schweizerisches Recht / Revue de droit suisse 237; Amstutz and Niggli (n 105); Papaux (n 105); Keshelava (n 105).

791 Pichonnaz and Vogenauer (n 105).

792 Arthur Meier-Hayoz, Schweizerisches Zivilgesetzbuch, Einleitung, Art. 1-1o ZGB (Stämpfli 1966) $138 \mathrm{f}$. 
'tactical eclecticism', ${ }^{793}$ 'a self-service store', 794 and 'cherry-picking without a clear concept ${ }^{795} .{ }^{796}$ They have shown that pragmatic methodological pluralism hardly constrains the Swiss Federal Tribunal, which is the sole arbiter of the results yielded by different methods ${ }^{797}$ (see infra, Chapter $5,3 \cdot 3$ ). They have also demonstrated that the Court, which must imperatively reach a decision and, in this sense, be result-oriented ('pragmatic'), is often primarily guided by teleology. ${ }^{798}$

\subsubsection{The Legal Authority of Domestic Rulings in the Swiss Legal Order}

Lastly, we must clarify the legal authority that court rulings enjoy in the Swiss legal order, ie, the extent to which Swiss judicial decisions are a source of domestic law ${ }^{799}$ (on their legal effect in international law, see infra, Chapter 4, section 3). When we talk about judicial lawmaking, what is at stake is not only courts' decisional authority, ie, their authority to settle a particular case, but also their (potential) interpretive authority, ie, their legal authority in a given legal order beyond this particular dispute (eg in the context of future interpretations of the law). ${ }^{800}$

Art. 1 of the Swiss Civil Code, which applies to the Swiss legal order, is particularly interesting (though ambiguous) in this regard. It provides that the court, in the absence of an applicable legal provision, must decide based on customary law 'and, in the absence [thereof], in accordance with the rule that it would make as a legislator.801 The position Swiss courts and lawyers adopt towards judges' interpretive authority is influenced by the commitment of the Swiss

793 Yann Grandjean borrows this expression from French scholar Jean Carbonnier. See Grandjean (n 175) 370.

$794 \operatorname{Kramer}(\mathrm{n}$ 105) 179.

795 Kunz, 'Umgang mit internationalem und mit europäischem Recht. Überblick über den "Swiss Approach"' (n 764) 270.

796 See also Besson and Ammann (n 97) 339.

797 Grandjean (n 175) 370.

798 Pichonnaz and Vogenauer (n 105) 424 f; Grandjean (n 175) 370; Besson and Ammann (n 97) $340 \mathrm{ff}$.

799 On this issue, see Riccardo Guastini, 'Les juges créent-ils du droit? Les idées de Alf Ross' (2014) 24 Revus 99; Jan Komárek, 'Judicial Lawmaking and Precedent in Supreme Courts' (2011) 4 <eprints.lse.ac.uk/38468/1/WPS2011-04_Komarek.pdf>; Michel van de Kerchove, 'La jurisprudence revisitée : un retour aux sources' in Isabelle Hachez and others (eds), Les sources du droit revisitées - Vol 2 : Normes internes infraconstitutionnelles (Anthémis/Publications des Facultés universitaires Saint-Louis 2012).

8 oo On this distinction, see Besson, "The Erga Omnes Effect of Judgments of the European Court of Human Rights - What's in a Name?' (n 137).

801 Art. 1(2) SCC. 
polity to the rule of law and legislative supremacy (supra, 3.3 and 3.5). They typically consider that the law is the basis and limit of Swiss judges' activity, and that judges must apply, not make law. ${ }^{802}$ In short, they do not deem judicial rulings a source of domestic law. Although the Swiss Federal Tribunal does not see itself as a 'juridical machine' or a 'subsumption automaton', 803 it often uses mechanistic, non-evaluative language and emphasizes the syllogism that characterizes deduction ${ }^{804}$ without mentioning its creative effect. Swiss scholars have defined the judge as a 'person whose syllogistic reasoning produces legal effects'. ${ }^{805}$

Still, art. 1(2) of the Swiss Civil Code shows that judicial lawmaking is not unfamiliar to the Swiss legal order. In cases pertaining to domestic law, the Swiss Federal Tribunal has acknowledged the need for judges to interpret the law 'in light of [its] general development and of contemporary circumstances' when legislative intent is indeterminate. ${ }^{806}$ It has also used the notions of lawmaking, law development, adjustment, and gap-filling when describing the task of judges. ${ }^{807}$

The conditions under which the Court engages in dynamic interpretation are narrow. ${ }^{808}$ Nonetheless, the Court has assumed a lawmaking role in some areas of domestic law, including in constitutional law. In a way that, mutatis mutandis, reminds us of the us Supreme Court's unenumerated rights adjudication, ${ }^{809}$ the Swiss Federal Tribunal has identified several unwritten

$8 \mathrm{o} 2$ Karl-Ludwig Kunz, 'Politisches Engagement und die Unbefangenheit des Richters' in Marianne Heer, Marcel Alexander Niggli, and Marc Thommen (eds), Toujours agité jamais abattu: Festschrift für Hans Wiprächtiger (Helbing \& Lichtenhahn 2011).

803 Hans Peter Walter, 'Der Methodenpluralismus des Bundesgerichts bei der Gesetzesauslegung' (1999) 17 recht 157, 157. See however Ehrenzeller, Schindler, and Schweizer (n 382$) 3049$.

804 BGE $98 \mathrm{Ib}_{385}$, at 2 a).

805 Grandjean (n 175) 366 .

806 BGE 86 IV 92, at b).

807 BGE $137 \mathrm{~V} \mathrm{167}$, at 3.2; BGE $137 \mathrm{~V} \mathrm{126}$, at 4.1; BGE $137 \mathrm{~V} 9$ o, at 5.2; BGE $128 \mathrm{~V} 108$, at

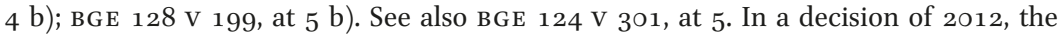
Swiss Federal Tribunal has stated that besides the protection of individuals, the task of the judiciary (at least as regards the highest court) is the uniform application of the law, as well as law development. See BGE $138 \mathrm{~V} 271$, at 3.3. It has also noted that 'pursuant to contemporary conceptions, to apply a prima facie clear legal norm by analogy to a particular situation at which the norm is not aimed is an act of judicial lawmaking, and not an inadmissible interference with legislative power', see BGE $127 \mathrm{~V} \mathrm{484,} \mathrm{at} 3$ b) bb).

808 Thus, in a decision pertaining to guardianship rights, the Swiss Federal Tribunal dismissed scholarly criticism according to which the Court had ignored new legal developments, stating that it was a 'law-applying' authority which could only exceptionally depart from the law (BGE 123 III 445, at 2 b)). See also BGE 124 V 159, at 4 c).

809 Griswold v. Connecticut, 381 U.s. 479 (1965). 
fundamental rights ${ }^{810}$ based on existing provisions of the Federal Constitution $^{811}$ and of cantonal constitutions. This case law was subsequently codified in the 1999 revision of the Federal Constitution. ${ }^{812}$ Judges themselves note in their writings that interpretation involves evaluation, ${ }^{813}$ and Swiss scholarship increasingly emphasizes the creative dimensions of judicial reasoning. ${ }^{814}$

The orthodox doctrine based on which courts must remain independent from the political branches and especially from the legislature sits uneasily with judges' power to make law in individual cases, and even to influence the formation and development of domestic ${ }^{815}$ law. Yet all three branches of government have lawmaking powers, even if they must exercise them separately in their respective domains of activity, without interfering with one another. Swiss courts make law in individual cases. In doing so, they also influence future interpretations of the law.

The Swiss legal order is characterized by a range of specificities that affect and constrain Swiss courts' activity, including when they apply international law.

810 Gonin and Bigler (n 702) 22 ff; Andreas Kley, 'Der Grundrechtskatalog der nachgeführten Bundesverfassung: Ausgewählte Neuerungen' (1999) 135 Zeitschrift des Bernischen Juristenvereins 301; Hertig Randall and Chatton (n 441) 393. One example of such an unwritten constitutional right is the right to personal freedom, see BGE 89 I 92, at 3 f; Kley $319 \mathrm{ff}$. Another example is the right to secure one's livelihood, see BGE 121 I 367, at 2.

811 The Court has especially relied on the right to equality, protected by art. 4 of the Swiss Constitution of 1874. See Gonin and Bigler (n 702) 23.

812 Federal Council, Botschaft über eine neue Bundesverfassung, 2 O November 1996, FG 1997 I 1, at 115. More generally, a range of constitutional and statutory provisions have been enacted or amended to reflect the Swiss Federal Tribunal's case law. See for instance Federal Council, Botschaft über die Genehmigung und die Umsetzung des Notenaustauschs zwischen der Schweiz und der EG betreffend die Übernahme der EG-Rückführungsrichtlinie (Richtlinie 2008/115/EG) und über eine Änderung des Bundesgesetzes über die Ausländerinnen und Ausländer (Automatisierte Grenzkontrolle, Dokumentenberaterinnen und Dokumentenberater, Informationssystem MIDES), 18 November 2009, FG 2009 8881, at 8901 (regarding art. 81(2) FA-FN); Federal Council, Botschaft zur Änderung des Strafgesetzbuches (Allgemeine Bestimmungen, Einführung und Anwendung des Gesetzes) und des Militärstrafgesetzes sowie zu einem Bundesgesetz über das Jugendstrafrecht, 21 September 1998, FG 1999 II 1979, at 2000 (on title 2 of the SCrimC), 2062 (regarding art. 5o SCrimC), and 2087 (regarding art. 62c(2) phrase 2 SCrimC).

813 Seiler (n 712); Albrecht (n 712).

814 Ehrenzeller (n 638); Papaux (n 105); Amstutz and Niggli (n 105).

815 There is an analogous uneasiness vis-à-vis judges' contribution to the formation of international law, see Chapter 4, section 3 (infra). 
Swiss foreign affairs give prominence to some areas of international law, while other areas are relatively unimportant in practice. This influences the issues likely to be brought before Swiss courts. The monism of the Swiss legal order entails that international law can immediately be applied by Swiss courts once it becomes binding on their State. Courts hence typically interpret international laws that have not gone through a domestic legislative filter. The rank of international law in the Swiss legal order is not settled, and in some cases, especially in connection with the so-called 'Schubert Praxis', courts have made domestic laws trump international law. A similar ambivalence can be noticed regarding direct effect, which courts interpret in a way that is at times open, at times closed towards international law. In this context, courts' interpretative reasoning lacks predictability, clarity, and consistency, and it does not demonstrably conform with the interpretative methods of international law.

Courts' activity, including as regards international legal issues, is conditioned by several principles that structure the Swiss polity. Federalism protects the interests and competences of the cantons. Linguistic diversity influences the composition of the federal authorities, and it impacts federal legislation and judicial proceedings. It may also create interpretative divergence. Another important constraint on Swiss judges is their duty to abide by the law and to respect international law, which flows from the Swiss constitutional principle of the rule of law. Instruments of direct democracy give Swiss voters the possibility to shape Switzerland's foreign policy. As a result, clashes between domestic and international law may come to the fore in the courts. The supremacy of the federal legislature over other Swiss authorities explains Switzerland's weak system of judicial review, and Swiss judges' deference towards federal acts, especially when the legislature willingly derogates from international law.

The Swiss judiciary has several layers. The Swiss Federal Tribunal has jurisdiction over international legal issues, except for some foreign relations matters. Nonetheless, the Court often defers to other federal authorities, at least with regard to some questions of international law. Swiss courts have the duty to apply international law and to respect the State's international obligations. While the Swiss legal order is committed to the rule of law, Swiss judges are not insulated from the influence of politics. They are elected by the parliament or, in some cases, by the people. Moreover, they are in office for a limited period. Yet judges' accountability towards their constituency is hampered by the fact that rulings typically only reflect the opinion of the majority. As regards Swiss courts' interpretative approach, the Swiss Federal Tribunal endorses 'pragmatic methodological pluralism', which consists in a result-oriented balancing of considerations yielded by textual, teleological, systematic, and historical 
interpretation. Judicial decisions are not typically acknowledged as a source of domestic law by the State authorities. However, judicial decisions influence the interpretation of the law in subsequent cases. Moreover, the Swiss Federal Tribunal has contributed to the identification, formation, and modification of domestic law, including constitutional law. 